\title{
ESPAÇOS LIVRES, A PERCEPÇÃO DO CALOR EM UMA CIDADE CONTINENTAL, O INVERNO DE 2018 - DOURADOS (MS / BRASIL)
}

\author{
REMELLI, Andressa Garcia - dressaremelli@hotmail.com \\ Universidade Federal da Grande Dourados / UFGD \\ SILVA, Charlei Aparecido - charleisilva@ufgd.edu.br \\ Universidade Federal da Grande Dourados / UFGD
}

Submetido em: $30 / 10 / 2020$

Aceito para publicação em: 07/04/2021

Publicado em: $17 / 04 / 2021$

DOI: http://dx.doi.org/10.5380/abclima.v28i0.77627

\begin{abstract}
RESUMO: Compreender a percepção climática dos transeuntes e frequentadores de espaços livres da cidade de Dourados (MS), Brasil, levando em consideração a avaliação do (des)conforto térmico, é o objetivo ora proposto. O estudo refere-se ao inverno de 2018. A escolha pelo inverno se dá em função do registro de grandes amplitudes térmicas, decorrente de sistemas tropicais mTc (Massa Tropical Continental) e mTa (Massa Tropical Atlântica) em alternância com a mPa (Massa Polar Atlântica) e frentes frias. Foram realizadas coletas de dados de temperatura do ar, umidade relativa e velocidade do vento na escala horária, a qual é a mais adequada aos objetivos da pesquisa. Questionários foram aplicados em transeuntes e frequentadores dos espaços analisados. As informações foram correlacionadas com a condição da circulação atmosférica regional, condição que permitiu a identificação das condições predominantes do tempo quando da realização do estudo. Observa-se que as condições de conforto térmico são mais favoráveis no início da manhã, o tempo se mostrou mais agradável com temperaturas amenas que variaram de $16,8^{\circ} \mathrm{C}$ até $22,9^{\circ} \mathrm{C}$. As máximas de temperatura do dia alcançaram os valores de $31,47^{\circ} \mathrm{C}$ até $38,26^{\circ} \mathrm{C}$, provocando um desconforto $(26<$ ID $\geq 28$ ). A máximas da umidade do ar variaram de $44,48 \%$ a $73,84 \%$, com mínimas de $15 \%$ a $30,96 \%$. A velocidade do vento oscilou entre $8,4 \mathrm{~m} / \mathrm{s}$ de máxima e mínimas de 0 $\mathrm{m} / \mathrm{s}$. No período analisado não foi registrado IDT de muito desconforto (ID $\geq 28$ ), mas chama atenção o registro de IDT $(26<$ ID $\geq 28)$ no período do inverno. Observa-se a importância do padrão construtivo na determinação da percepção do calor. Espera-se que o estudo colabore a proposição de políticas públicas, com pesquisas de clima urbano de cidades continentais, essencialmente aquelas que apresentam temperaturas elevadas em grande parte do ano.
\end{abstract}

PALAVRAS-CHAVE: Clima urbano, percepção climática, metodologia IDT.

OPEN SPACES, THE PERCEPTION OF HEAT IN A CONTINENTAL CITY, THE WINTER OF 2018 - DOURADOS (MS / BRAZIL)

ABSTRACT: Understanding the climatic perception of passers-by and frequenters of open spaces in the city of Dourados (MS), Brazil, taking into account the assessment of thermal (un) comfort, is the objective herein proposed. The study refers to the winter of 2018. The choice for winter is due to the record of large temperatures ranges, resulting from tropical systems cTm (Continental Tropical Mass) and aTm (Atlantic Tropical Mass) alternating with $\mathrm{mPa}$ (Atlantic Polar Mass) and cold fronts. Collections of data on air temperature, relative humidity and wind speed on the hourly scale, which is the most appropriate for the research objectives. Questionnaires were applied to passers-by and visitors of the analyzed spaces. The information was correlated with the condition of the regional atmospheric circulation, which allowed the identification of the predominant weather conditions at the time of the study. It is observed that the thermal comfort conditions are more favorable in the early morning, the weather was more pleasant with mild temperatures that ranged from $16.8^{\circ} \mathrm{C}$ to $22.9^{\circ} \mathrm{C}$. The maximum temperature of the day reached the values of $31.47^{\circ} \mathrm{C}$ up to $38.26^{\circ} \mathrm{C}$, causing discomfort ( $26<$ ID $\geq 28$ ). Air 
humidity highs ranged from $44.48 \%$ to $73.84 \%$, with lows from $15 \%$ to $30.96 \%$. Wind speed ranged from $8.4 \mathrm{~m} / \mathrm{s}$ maximums to lows of $0 \mathrm{~m} / \mathrm{s}$. In the analyzed period, no RTD of very discomfort (ID $\geq 28$ ) was recorded, but it draws attention the record of RTD $(26<$ ID $\geq 28)$ in the winter period. The importance of building pattern in determining heat perception is observed. The study is expected to contribute to the proposition of public policies, with urban climate research in continental cities, essentially those that present high temperatures during most of the year.

KEYWORDS: Urban climate, climate perception, methodology IDT.

\section{ESPACIOS ABIERTOS, LA PERCEPCIÓN DEL CALOR EN UNA CIUDAD CONTINENTAL, INVIERNO 2018 - DORADO (MS / BRASIL)}

RESUMEN: Comprender la percepción climática de los transeúntes y frecuentadores de espacios abiertos en la ciudad de Dourados (MS), Brasil, teniendo en cuenta la evaluación del (des) confort térmico, es el objetivo propuesto. El estudio se refiere al invierno de 2018. El elección para el invierno se debe al registro de grandes amplitudes térmicas, resultantes de los sistemas tropicales mTc (Masa Tropical Continental) y mTa (Masa Tropical Atlántica) alternando con mPa (Masa Polar Atlántica) y sistemas frontales frío. Se recogieron colecciones de datos de temperatura del aire, humedad relativa y velocidad del viento en la escala horaria, que es la más adecuada para los objetivos de la investigación. Se aplicaron cuestionarios a los transeúntes y frecuentadores de los espacios analizados. La información se correlacionó con la condición de la circulación atmosférica regional, condición que permitió identificar las condiciones climáticas predominantes cuando se realizó el estudio. Se observa que las condiciones de confort térmico son más favorables en la madrugada, el clima fue más agradable con temperaturas suaves que variaron de $16.8^{\circ} \mathrm{C}$ a $22.9^{\circ} \mathrm{C}$. La temperatura máxima del día alcanzó los valores de $31,47^{\circ} \mathrm{C}$ a $38,26^{\circ} \mathrm{C}$, provocando malestar $(26<\mathrm{DI} \geq 28)$. La humedad máxima del aire osciló entre $44,48 \%$ y $73,84 \%$, con una mínima de $15 \%$ a $30,96 \%$. La velocidad del viento osciló entre un máximo de $8,4 \mathrm{~m} /$ sy un mínimo de $0 \mathrm{~m}$ / s. En el período analizado, no hubo registro de mucho malestar (DI $\geq 28$ ), pero destaca el registro de IDT $(26<$ DI $\geq 28)$ en el período invernal. Se observa la importancia del patrón de construcción en la determinación de la percepción del calor. Se espera que el estudio contribuya a la proposición de políticas públicas, con encuestas de clima urbano en ciudades continentales, fundamentalmente aquellas que presentan altas temperaturas durante la mayor parte del año.

PALABRAS CLAVE: Clima urbano, percepción climática, metodologia IDT.

\section{INTRODUÇÃO}

As cidades atualmente são responsáveis por abrigar os maiores contingentes populacionais. Como resultado, a produção do espaço urbano, gera mudanças alicerçadas nas atividades humanas e consequentemente altera as condições da atmosfera na escala local, essa condição já foi evidenciada em diversas partes do mundo, como destacam Oke (1978) e Lombardo (1985).

Rampazzo e Sant'Anna Neto (2012) registram como que o crescimento das cidades altera as características da atmosfera local, que por consequência acaba estabelecendo um clima urbano particular, além de estar estreitamente relacionado a qualidade ambiental como a vida da população, isto principalmente devido aos índices de temperatura, poluição do ar e umidade relativa:

A superfície natural torna-se predominantemente impermeabilizada devido à concentração de áreas construídas, associada à maior inércia térmica dos materiais devido às propriedades térmicas diferenciadas, dificultando a infiltração da água e o escoamento areolar e retendo/armazenando uma maior quantidade de calor durante os 
O clima urbano produzido nas cidades está estreitamente relacionado com a produção do espaço urbano que se manifesta por meio da organização territorial, pela intensidade do adensamento populacional, da infraestrutura urbana, da própria localização geográfica, assim como sua relação com o entorno. Inúmeros são os problemas socioambientais gerados pela ausência de planejamentos urbanos, principalmente ligados ao crescimento dos espaços urbanos desordenados, que resultam em enchentes e alagamentos, poluição do ar e das águas e as temperaturas cada vez mais elevadas em microescala (SILVA et al., 2015, p. 163). Soma-se a isso a não inclusão do clima como uma variável importante dos planejamentos urbanos e mesmo nas políticas públicas.

Ao se buscar a compreensão do clima urbano de um lugar é necessário avaliar estas variáveis expostas acima, de modo que a produção do espaço urbano irá ajudar a traçar as características do ambiente urbano no qual estes diferentes aspectos acabam influenciando e refletindo com maior ou menor intensidade no clima urbano gerado.

Este trabalho tem um objetivo distinto daqueles realizados até o momento sobre a dinâmica climática da cidade de Dourados, Mato Grosso do Sul, Brasil, situado na latitude $22^{\circ} 16^{\prime} 30^{\prime \prime} \mathrm{S}$ e longitude 54049'00W. (Figura 1). Seu propósito foi de analisar o entendimento, a percepção climática, dos frequentadores de espaços livres da cidade, isso por meio de questionários, tomando como parâmetro elementos do tempo atmosférico que são percebidos com mais facilidade pelo ser humano, cita-se, a temperatura do ar, a umidade do ar e a velocidade do vento. Atrelando esses elementos a percepção dos entrevistados a fim de determinar índices de conforto térmico.

Diante destas considerações é possível compreender a necessidade de se pensar sobre o conforto térmico para além dos projetos de edificações em ambientes fechados, sendo necessário que está ideia perpasse para os ambientes abertos, que os mesmos se tornem lugares agradáveis e que possam cumprir a premissa fundamental de minimizar o desconforto causado por temperaturas elevadas. Estudos de climatologia urbana sobre o viés do conforto térmico nos permite compreender como que as ações no ambiente atmosférico interferem e se relacionam com os indivíduos, isso se torna foco central da pesquisa sobre a percepção climática. 

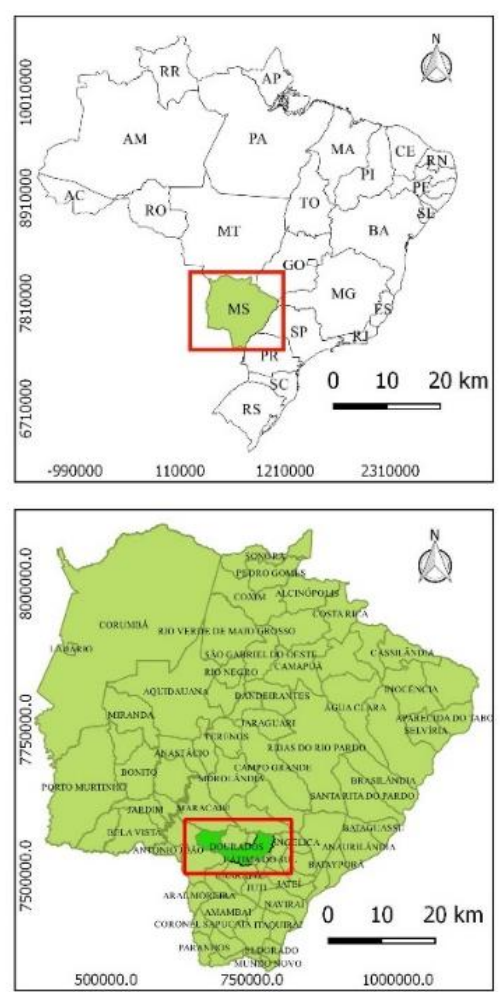

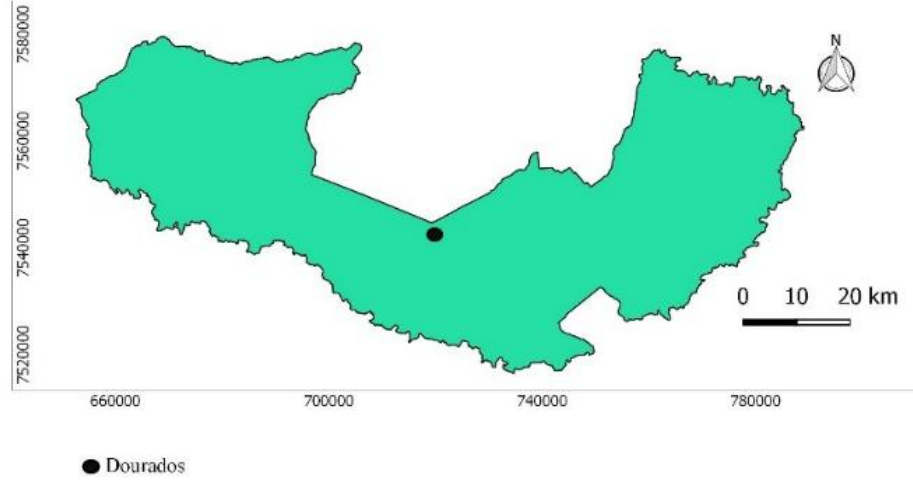

Figura 1 - Localização do município de Dourados-MS. Fonte dos dados: IBGE (2016) Acesso 20 de janeiro de 2018. Elaboração: Os autores (2020).

A satisfação psicológica e fisiológica do organismo humano, está estreitamente ligado as atividades desenvolvidas, sua vestimenta e sua relação com o ambiente que está a seu redor. Sabe-se que o sistema termorregulador entra em ação e ativa a manutenção do equilíbrio corpo com a temperatura ambiente (VIANA, 2012). Isso demostra que a percepção climática tem uma relação muito próxima a de conforto térmico, uma vez que as condições do tempo vão afetar a percepção humana e a forma como cada organismo percebe.

Nesta perspectiva, ao considerar os danos gerados pelo modelo de ocupação do solo e adensamento construtivos, é necessário introduzir as contribuições dos estudos climáticos junto a legislação e aos códigos de edificações, e, também nos planos diretores. Fato, será mais difícil mostrar a importância desses condicionantes nas construções e os impactos causados se não estiverem integradas a estes regulamentos que normatizam o espaço urbano.

Face ao exposto, porque escolher espaços livres como objeto de análise? Dumazedier (1973) revela que os parques urbanos surgem numa tentativa de amenizar as estruturas urbanas, em um cenário do século XIX, no qual era ampliado o processo de lazer urbano no contexto da industrialização. Estes espaços teriam a função de melhorar a qualidade de vida de seus habitantes, condição vista ainda nos dias atuais, ou seja, mesmo com o decorrer do tempo estes espaços ainda exercem a mesma função.

Existem inúmeras discussões sobre qual conceito adotar naquilo que concerne a tipologia para determinar estes espaços no meio urbano: espaços verdes, áreas verdes, parques urbanos, espaços livres e praças. Deste modo, 
optou-se por seguir a perspectiva de espaços livres contido na proposta de Andrade (2009), em que se expõe o livre no sentido de acessibilidade física de livre acesso, e como o próprio autor apresenta, o uso dos conceitos se modifica conforme o objetivo de cada pesquisa e das metodologias adotadas.

Dessa forma, os espaços livres se tornam um elemento importante, visto que $84 \%$ da população brasileira reside em áreas urbanas (IBGE, 2010). O sítio urbano sofre alterações devido ao crescimento e desenvolvimento das cidades, essas alterações se apresentam principalmente relacionadas ao tipo de material utilizado para construção, a falta de infraestrutura básica (planejamento urbano) que vão influenciar na alteração dos processos e dinâmicas naturais neste ambiente. O clima urbano será resultado dessas alterações e características.

No cenário atual, estes espaços livres se tornam uma premissa importante para a qualidade de vida urbana, já que os mesmos criam inúmeros benefícios, cita-se a criação de microclimas mais agradáveis que, em última instância, irá se refletir de forma relevante sobre a dinâmica de ilhas de calor e domo de poluição (TROPPMAIR E GALINA, 2003). Não menos importante são elementos relevantes para determinar o conforto térmico das cidades e um indicador da saúde urbana.

Conforme mencionado por Lima e Amorin (2006 p. 139), "a população urbana depende para o seu bem-estar, não só de educação, cultura, equipamentos públicos, mas também de um ambiente com qualidade, $\mathrm{e} a$ vegetação quando presente interfere positivamente na qualidade de vida dos habitantes". Desta maneira, estes espaços desempenham a função de propiciar lazer e espaço de convivência entre seus frequentadores. Para determinados grupos é a única opção de lazer acessível, sendo assim deveriam ser espaços que permitam que sejam utilizados em qualquer horário do dia, levado em consideração o conforto térmico adequado.

Em síntese, avaliar o conforto e/ou desconforto térmico nestes espaços livres de forma mais ampla e transversal na cidade de Dourados (MS) parece essencial nesse momento no qual registra-se um significativo crescimento de sua malha urbana.

\section{METODOLOGIA}

O objetivo do trabalho foi de compreender a percepção climática dos transeuntes e frequentadores dos espaços livres da cidade de Dourados, e, avaliar o (des)conforto térmico a partir do parâmetro IDT (Índice de Desconforto Térmico) proposto por Thom (1959), adaptado por Santos et al., 2012 para regiões tropicais. O IDT é um dos mais utilizado e citado na bibliografia nacional e internacional segundo Fante, Dubreuil e Sant'Anna Neto (2017) condição que permite comparações com outros estudos que tenham o mesmo escopo. Fez-se uso assim de procedimentos, métodos e técnicas que congregaram, articularam, a revisão de literatura, a aplicação de questionários e a coleta de dados primários de temperatura, umidade relativa e ventos. A escolha dos parâmetros temperatura, umidade relativa e ventos se deu a partir de equipamentos portáteis, mini abrigos meteorológicos e convergem com 0 índice escolhido, o IDT. 
A seleção dos espaços livres seguiu os critérios de Remelli e Silva (2018). Ocorreu o levantamento de documentos públicos do município, chegando-se ao total de dezoito espaços livres inicialmente. A partir de então, se elencou dois critérios fundamentais, o tipo de atividade desenvolvida naqueles espaços e a sua importância no contexto da cidade. Isso permitiu a seleção de dez espaços livres que receberam visitas in loco. Foram elencados oito critérios (Quadro 1) para se definir os quatro espaços mais representativos e importantes para analisar a percepção climática e o conforto térmico da cidade de Dourados (MS).

Quadro 1 - Critérios de escolha dos espaços livres. Fonte: Remelli (2019).

\section{CRITÉRIOS}

Localização

Espacial

dentro da

cidade

Tamanho e

importância da

área para

cidade

\section{Características e Justificativas}

Foi levado em consideração a disposição dos espaços livres (praças e parques) dentro do espaço urbano da cidade de Dourados-MS. Ao observar a localização, fica constatado que grande maioria estão localizados próximos as áreas centrais e bairros de classe média/alta, uma vez que, nas áreas periféricas da cidade encontram-se dispersas ou ausentes.

No que concerne o tamanho e a importância do espaço livre analisado, estão relacionados ao fato destes locais serem reconhecidos por grande parte da população. Além disso, são espaços consideravelmente grandes com áreas de 400 a 2 mil metros, desta maneira, apresentam grande importância ao sistema de espaços livres e possivelmente para o conforto térmico.

O uso e ocupação do entorno tem e faz muita relação como

\section{Uso e ocupação do entorno} estes espaços livres são ocupados por seus frequentadores. Alguns espaços livres têm seu entorno composto de área comercial, seu uso fica destinado muitas vezes somente no uso de passagem. Além do mais, aqueles localizados em área residencial, acabam propiciando maior uso da população para atividades daquilo que o local tem a oferecer.

É aspecto relevante, uma vez que a estrutura do local reflete

Infraestrutura do local se há ou não ocupação por parte da população. No caso, há espaços que oferecem pista de caminhada, playground para as crianças, quadras poliesportivas e até pistas de skate e quiosques, isto faz com que a população acabe frequentando mais e assim se apropriando destes lugares.

Tipo de
atividade
desenvolvida
pelos
frequentadores

Este critério tem relação com o exposto acima, uma vez que o tipo de atividade desenvolvida tem relação mais intensa com aquilo que o espaço livre tem a oferecer. Mesmo assim, há aqueles que vão a estes espaços somente para passar o tempo, exercitar o ócio, rodas de tereré e também sendo somente um local de passagem.

Este é um ponto importante, já que para compreender a

Fluxo de percepção climática dos frequentadores, é necessário que o pessoas que frequentam e fazem uso dos espaços. 


\section{Presença ou ausência de vegetação}

A presença ou ausência de vegetação é um importante condicionante térmico. Muitas vezes estes espaços não são pensados perante a realidade do clima, tornando-se locais em sua maior parte do tempo inutilizável, já que não possui uma vegetação que proteja seus frequentadores da radiação solar.

À presença ou não de vegetação rasteira, influencia no Nível de área
permeável e
impermeável aquecimento ou resfriamento das superfícies destes espaços livres. Sendo assim, a ausência de áreas permeáveis acaba gerando em dias de muita insolação, ambientes impróprios para permanência de seus frequentadores. Também pode ser levado em conta que, as áreas permeáveis acabem ajudando no escoamento e infiltração de águas pluviais, desta maneira, isso gera benefícios e ainda é de suma importância para a dinâmica da cidade.

Entre os equipamentos utilizados para a execução da pesquisa estão: GPS, para identificar a coordenada geográfica de cada ponto analisado; termohigrômetro digital portátil, para coletar dados de temperatura do ar e umidade relativa e um anemômetro para se aferir a velocidade do vento. A fim de obterse o maior número de informações possíveis sobre a dinâmica do tempo e correlacionar os dados com a percepção e o conforto térmico definiu-se um intervalo de tempo de 15 minutos para amostragem dos parâmetros. O horário da coleta consistiu do período das 7 às 17 horas. Salienta-se, fez-se uso das propostas de Santos (2018) e Lopes e Jardim (2012) no que tange ao uso dos miniabrigos meteorológicos, Figura 2.
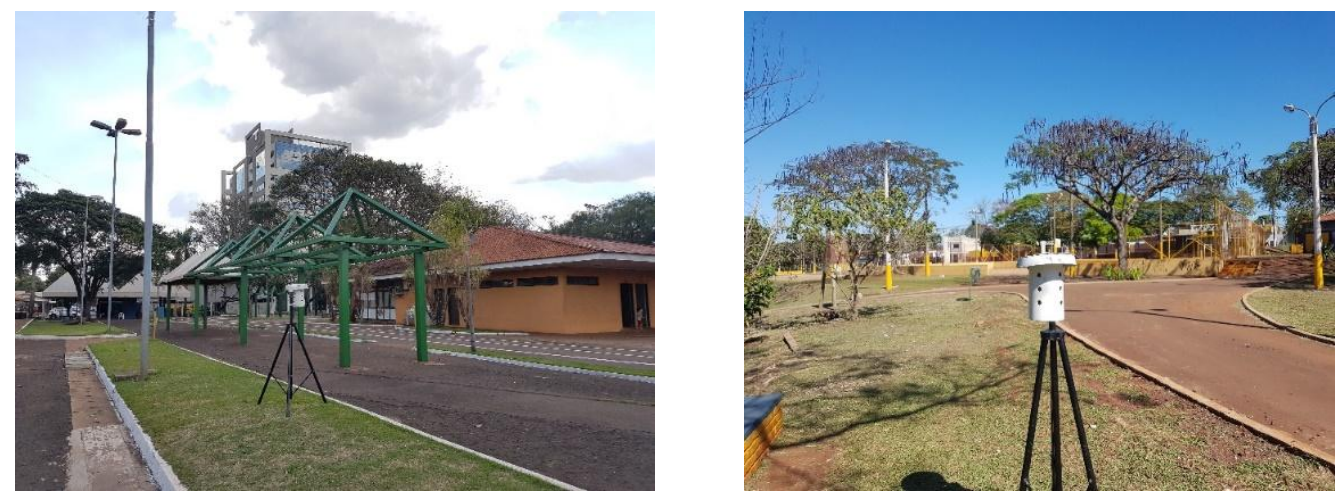

Figura 2 - Mini abrigo meteorológico em campo. Fonte: Remelli (2019).

O período definido para coleta dos dados e das informações nos espaços livres deu-se em função das características climáticas regionais, da dinâmica do clima e sua sazonalidade anual. Os episódios de inverno foram selecionados tendo como base a ideia de habitualidade e estabilidade do tempo, vista aqui como a ausência de chuvas. Determinou-se que a ocorrência de chuvas poderiam interferir diretamente nos valores aferidos da temperatura. Acreditase que a escolha do período, do episódio, desses parâmetros valida e estão adequados aos objetivos da pesquisa. 
Outro fator levado em consideração na definição do episódio é de que as condições do tempo permitissem a coleta dos dados, além disso, ter um número expressivo de frequentadores que pudessem responder o questionário elaborado a fim de obter-se dados sobre a percepção do tempo. O questionário utilizado foi sustentado nos princípios de percepção propostos por Sartori (2014) e no questionário aplicado por Gobo (2017), esse se apoiou na norma ISO 10551 (1995), e em Monteiro (2008).

Houve a preocupação de se registrar as condições visuais do tempo ao longo do período escolhido para amostragem, para isso se fez o uso de fotografias do céu. Esse procedimento demonstrou-se importante, permitiu registrar as mudanças do tempo na escala diária, sendo possível estabelecer uma correlação com as informações coletadas, tanto as qualitativas quanto as quantitativas. Para esta etapa foi definido os seguintes horários: 7 horas, às 12 horas e às 17 horas.

Para se avaliar o (des)conforto térmico foi utilizado o parâmetro do IDT (Índice de Desconforto Térmico) proposto por Thom (1959), que possibilita qualificar o estresse no ambiente urbano (COUTINHO et al., 2014) pela seguinte equação:

$$
I T U=T a-0,55(1-0,01 U R)(T a-14,5)
$$

No qual, o índice de desconforto térmico é denominado por Índice de Temperatura e Umidade (ITU), em que a temperatura ambiente (Ta) é dada em ${ }^{\circ} \mathrm{C}$, e a umidade relativa (UR) é dada em termos percentuais (\%). Santos et al., (2012), realizou ajustes (Quadro 2) para a classificação proposta por Thom, uma vez que a condição climática da área de estudo está sujeitada a zona tropical, diferente da proposta original que está para latitudes médias.

Quadro 2 - Faixas de classificação do índice de desconforto de Thom (ID) ajustados por Santos et al., 2012, para região tropical.

\begin{tabular}{ll}
\hline Descrição & Classes de Desconforto (ID) ( $\left.{ }^{\circ} \mathbf{C}\right)$ \\
\hline Bem-estar (confortável). & ID $<24$ \\
\hline Parcialmente confortável. & $24<$ ID $<26$ \\
\hline Desconfortável. & $26<$ ID $\geq 28$ \\
\hline Muito desconfortável. & ID $\geq 28$
\end{tabular}

Organização: Os autores.

Análise de cartas sinóticas de superfície auxiliaram na compreensão das condições do tempo durante a coleta dos dados e das informações, essencialmente no que se refere aos elementos do tempo atmosférico. Conforme apontado por Zavattini (2014), cartas sinóticas são úteis para o entendimento da dinâmica atmosférica e de suas variações no decorrer do dia, de modo que auxiliam na compreensão das características predominantes do tempo. Isso se apresentou como essencial para estabelecer relações diretas com os dados de percepção daqueles que utilizavam o espaço livre. 


\section{RESULTADOS}

O município de Dourados -MS, segundo o IBGE (2011) e a Embrapa Centro-Oeste (Embrapa- CPAO), tem com altitude máxima de 408 metros, sua topografia corresponde ao planalto de Dourados, sua vegetação nativa original tem correlação com os biomas Cerrado e Mata Atlântica.

Schneider e Silva (2012), a dinâmica climática posta:

[...] segundo (ZAVATINI, 1992, p. 85), Dourados encontra-se em uma faixa de limite zonal, havendo um equilíbrio na atuação dos fluxos extratropicais e intertropicais com pluviosidade anual variando entre $1500 \mathrm{~mm}$ e $1700 \mathrm{~mm}$, podendo chegar até $2000 \mathrm{~mm}$ em certos anos. Portanto segundo (MOURA, 2009), as características climáticas de Dourados se encontram dentro de um clima tropical úmido e seco [...] As massas de ar que atuam na região de Dourados/MS são destacadas como sendo basicamente três, tendo presença durante todo o ano, massa polar atlântica (mPa), massa tropical continental (mTc) e massa tropical atlântica ( $\mathrm{mTa}$ ) A sazonalidade da região permite com que essas massas de ar atuem com mais frequência ou não. As características climáticas atribuídas para o município estão inseridas em uma estação seca e outra chuvosa concomitantemente. (SCHNEIDER E SILVA, 2012, p. 61)

Os autores Fietz e Fisch (2008) e posteriormente numa atualização Fietz et al., (2017), avaliaram o clima da região de Dourados, no qual demostraram as seguintes informações: as temperaturas mais baixas ocorrem aos meses de maio a agosto, e as mais elevadas de setembro a abril.

Fato que merece destaque e que vai de encontro com a pesquisa, diz respeito a análise da série histórica, os dias muito quentes apresentaram a temperatura média superior de $33^{\circ} \mathrm{C}$ nos meses de agosto a novembro, isto se deve a maior amplitude térmica destes meses e das ondas de calor que se tornam comuns neste período (REMELLI, 2019). Estas informações se amarram ao objetivo geral da pesquisa, o da percepção climática e principalmente é visto no resultado da pesquisa.

Naquilo que se refere a umidade relativa do ar, "observa-se que nos meses que sucedem o verão o percentual é maior, ocorrendo contraditoriamente no inverno, que é o período com os menores índices de umidade relativa do ar" (REMELLI, op. Cit.). Por fim, sobre a velocidade do vento, nos meses de março a setembro há um aumento progressivo até atingir sua máxima, e nos meses de novembro a fevereiro ocorre uma diminuição. Este estudo também revela que a direção predominante do vento ocorra no sentido $\mathrm{NE}$, outra característica importante sobre o vento está sobre sua dinâmica no decorrer do dia. Conforme Fietz e Fisch (2008, p. 16): no período das 7 às 12 horas, a velocidade média tende a aumentar até alcançar seu valor máximo, das 13 às 6 horas a velocidade média passa a diminuir até chegar em seu valor mínimo.

A partir de todas estas informações a respeito da dinâmica climática e principalmente dos elementos que são importantes para a análise da percepção climática (temperatura do ar, umidade do ar e velocidade do vento) há necessidade de caracterizar e qualificar os espaços livres estudados e seu entorno, como segue: 
- Praça Antônio João: (Figura 3) sua implantação se deu na década de 1950, é considerada a praça mais antiga e a cidade acabou desenvolvendo em seu entorno, atualmente fica inserida no centro comercial na cidade. Uma característica importante e que a diferenciou das demais escolhidas diz respeito a sua função, uma vez que não exerce o papel de lazer a partir de equipamentos próprios, o espaço exerce principalmente a finalidade de passagem, espera, presença de ambulantes, realização de eventos destinados a população (culturais, religiosos, manifestações, etc.), inclui-se uma igreja que estimula o fluxo de pessoas.

A área permeável ocupa uma porcentagem muito pequena que se destina principalmente a canteiros, partindo da mesma direção há uma presença considerável de vegetação arbustiva, no entanto, elas não são suficientes para exercer conforto térmico, já que grande parte é totalmente concretada. O que acaba ajudando é que paralela à praça no canteiro central da avenida encontram-se árvores de grande porte e muito antigas que acabam fazendo sombra na praça durante todo o dia.
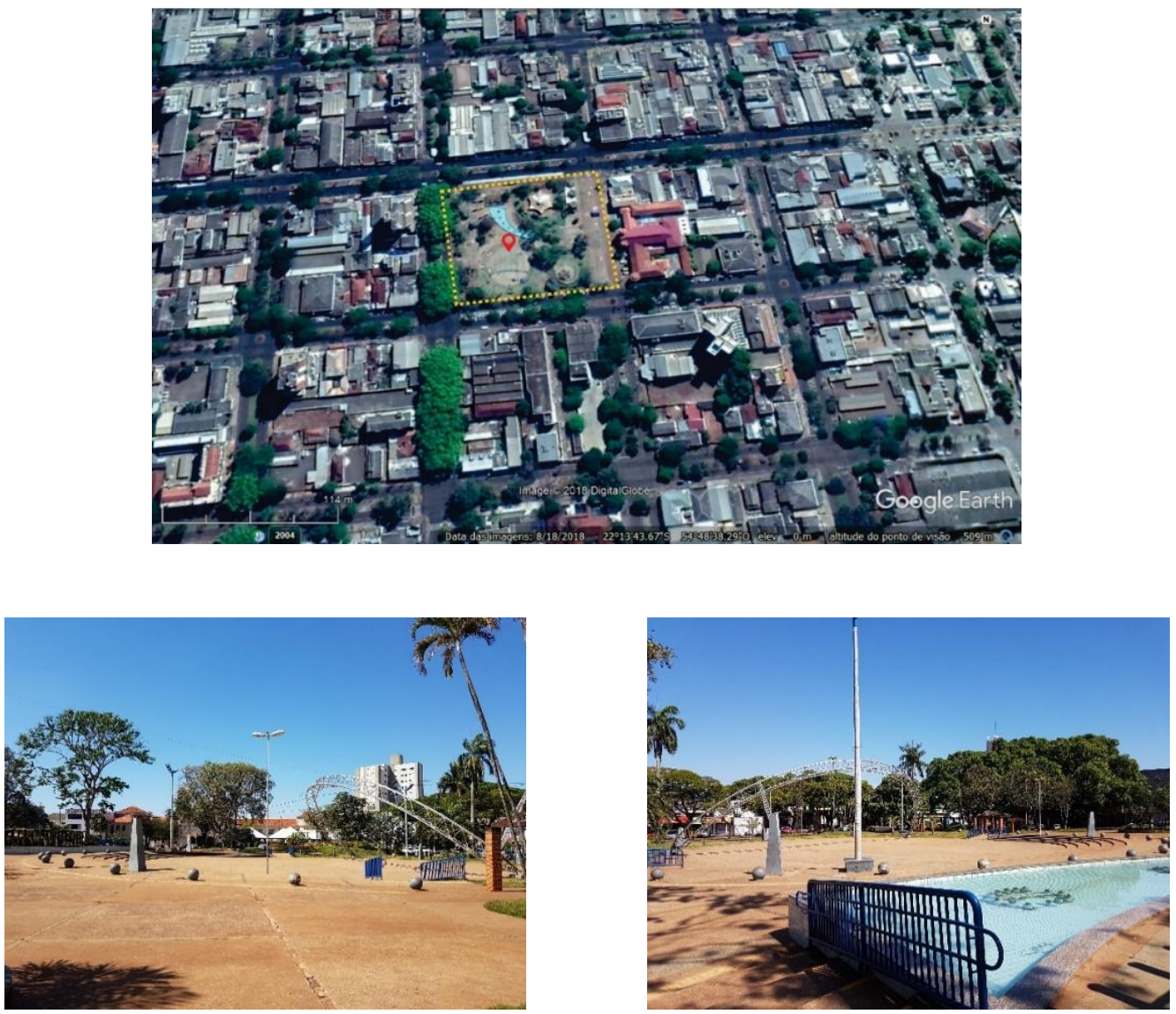

Figura 3 - Características espaciais e de estrutura física da Praça Antônio João. Fonte: Adaptado de Remelli, 2019. Organização: Os autores.

- Praça do Parque Alvorada: (Figura 4) este espaço livre se distingue dos demais por estar totalmente inserido num bairro residencial, o mesmo atrai diversos frequentadores dos bairros próximos, isso se deve muitas vezes por conta dos equipamentos oferecidos: quadra poliesportiva e de areia, pista de caminhada, pista de skate, playground e de uma academia com barras fixas, 
além de um enorme gramado. O entorno da praça é misto, conta com residências, pequenos comércios, igreja, escola, creche e academia, ainda é importante destacar sua proximidade com uma faculdade particular e da feira que acontece todas as quintas-feiras, em um espaço anexo a praça e a escola.

A partir do que foi apontado e daquilo observado In loco, o fluxo maior de utilização acontece logo no início da manhã e ao final da tarde para a prática esportiva e o uso do playground, isto se deve pela falta de arborização que permita o conforto térmico e consequentemente o uso deste espaço ao longo do dia, no qual seus frequentadores tem pouco lugares (somente um conjunto de parreiras) para se abrigar dos raios solares.
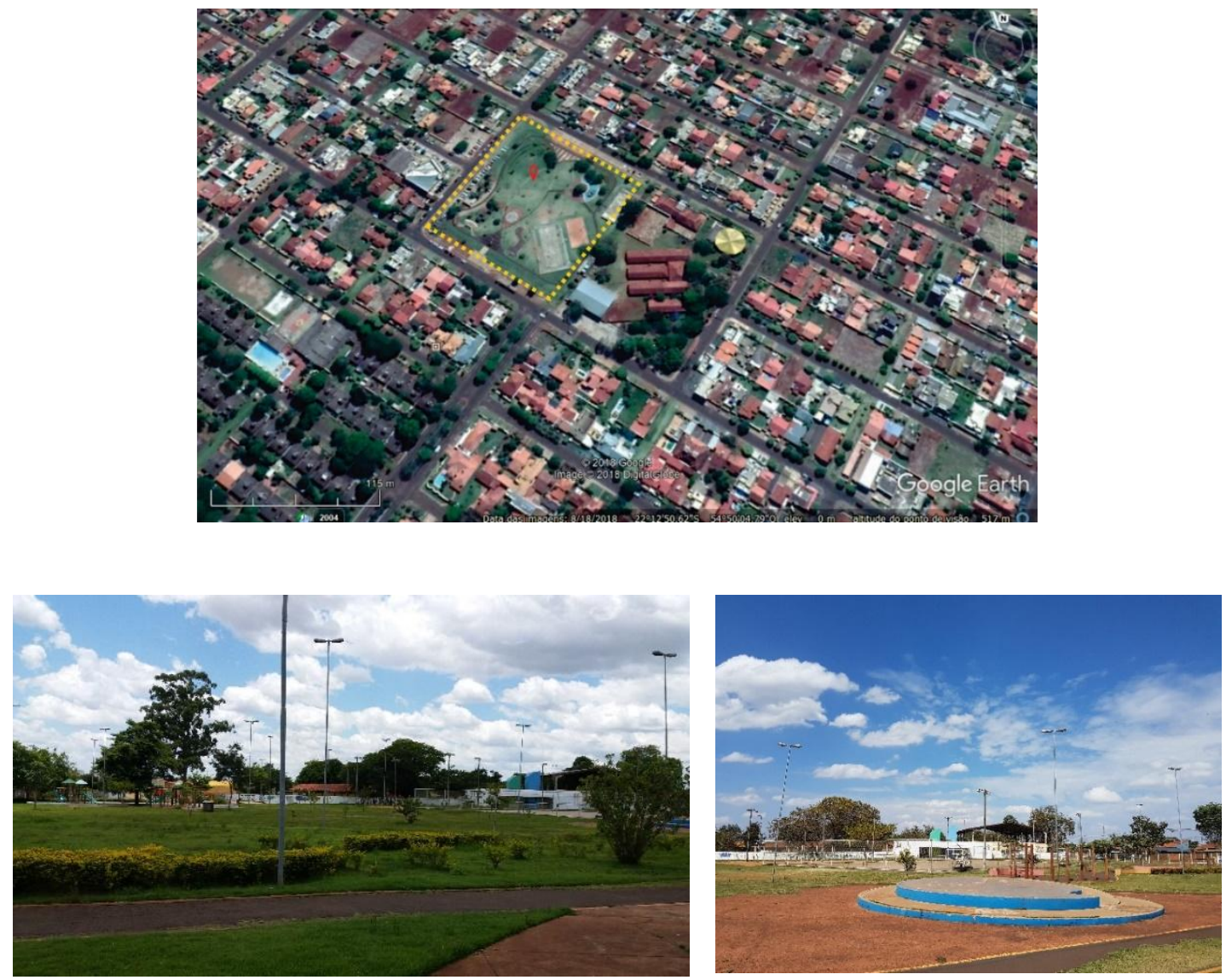

Figura 4 - Características espaciais e de estrutura física Parque Alvorada. Fonte: Adaptado de Remelli, 2019. Organização: Os autores

- Parque dos Ipês: (Figura 5) este espaço livre é um dos mais antigos da cidade, sua inauguração ocorreu no ano de 1995, se localiza próximo a área central e está cercado por bairros de alto padrão. Seu entorno ainda conta com a existência de restaurantes, mercado, academias, clínicas médicas, banco, escolas, salões de beleza, entre tantos outros serviços. Este é um espaço altamente utilizado pela população dos mais diferentes bairros da cidade, ocorre um fluxo constante durante todo o dia, somente de passagem, no horário do almoço para refeições e descanso, como para práticas de atividades físicas, e para o ócio. Mesmo assim, não difere dos outros espaços livres por apresentar um fluxo mais intenso no início da manhã e ao final do dia. 
O que torna este espaço singular em relação aos outros é que ele no decorrer do dia consegue manter um fluxo de pessoas devido a intensa arborização que o mesmo apresenta, em alguns dias é possível ver grupos de alunos de creche passando uma tarde no parque ou somente aproveitando da sombra que o lugar propicia. Outro ponto levado em consideração é quanto a área permeável, verifica-se que o lugar possuí um grande espaço permeável com gramado, quadra de areia e do playground.
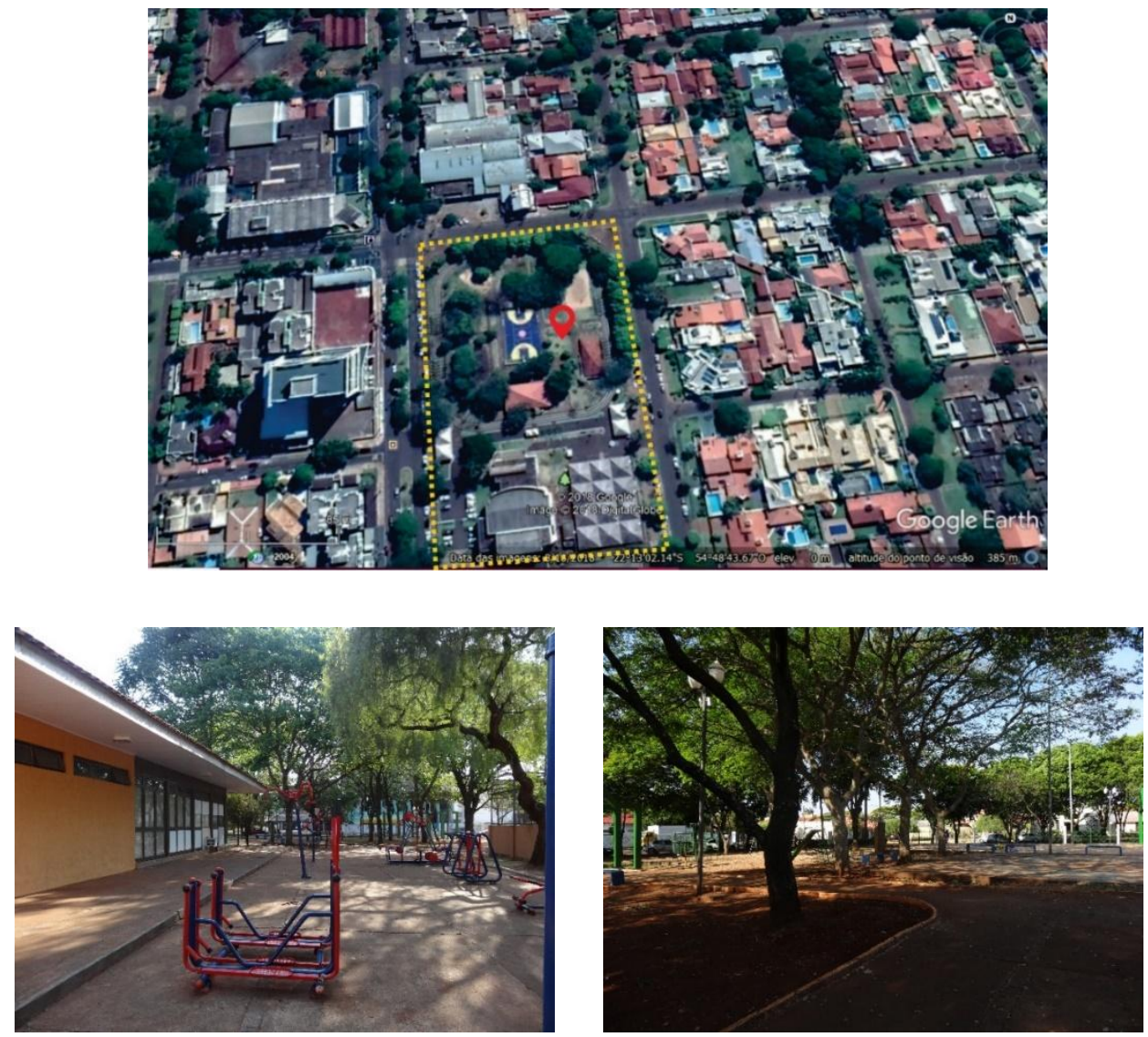

Figura 5 - Características espaciais e de estrutura física Parque dos Ipês. Fonte: Adaptado de Remelli, 2019. Organização: Os autores

- Parque Antenor Martins: (Figura 6) este espaço livre foi inaugurado em 1985, por meio de um plano CURA, que foi um plano de contemplações para a melhoria da estrutura urbana. Este parque é o maior da pesquisa, possuí uma área de $7.700 \mathrm{~m}^{2}$, possuindo grande área de drenagem, corpo d'água, vegetação arbustiva considerável em pontos específicos, ainda conta com pista de caminhada, quadras poliesportivas, academia ao ar livre, quiosques, banheiros, playground. Cabe ressaltar, que estes equipamentos existem, no entanto não é dada manutenção adequada ou os mesmos são alvo do vandalismo.

O espaço livre em sua maior parte do tempo é usado para realização de atividades físicas, playground, e por contar da metragem que possuí a população se reúne para rodas de conversa, tereré e contemplação do lago ou até mesmo somente como passagem já que o mesmo se encontra com seu entorno cercado de escolas, creches, comércios dos mais variados, postos de 
saúde, residências. Fica claro que o Parque Antenor Martins é o mais diversificado e atende vários bairros próximos, sendo umas das poucas opções de lazer, já que a população que mora ao seu entorno é mais carente.
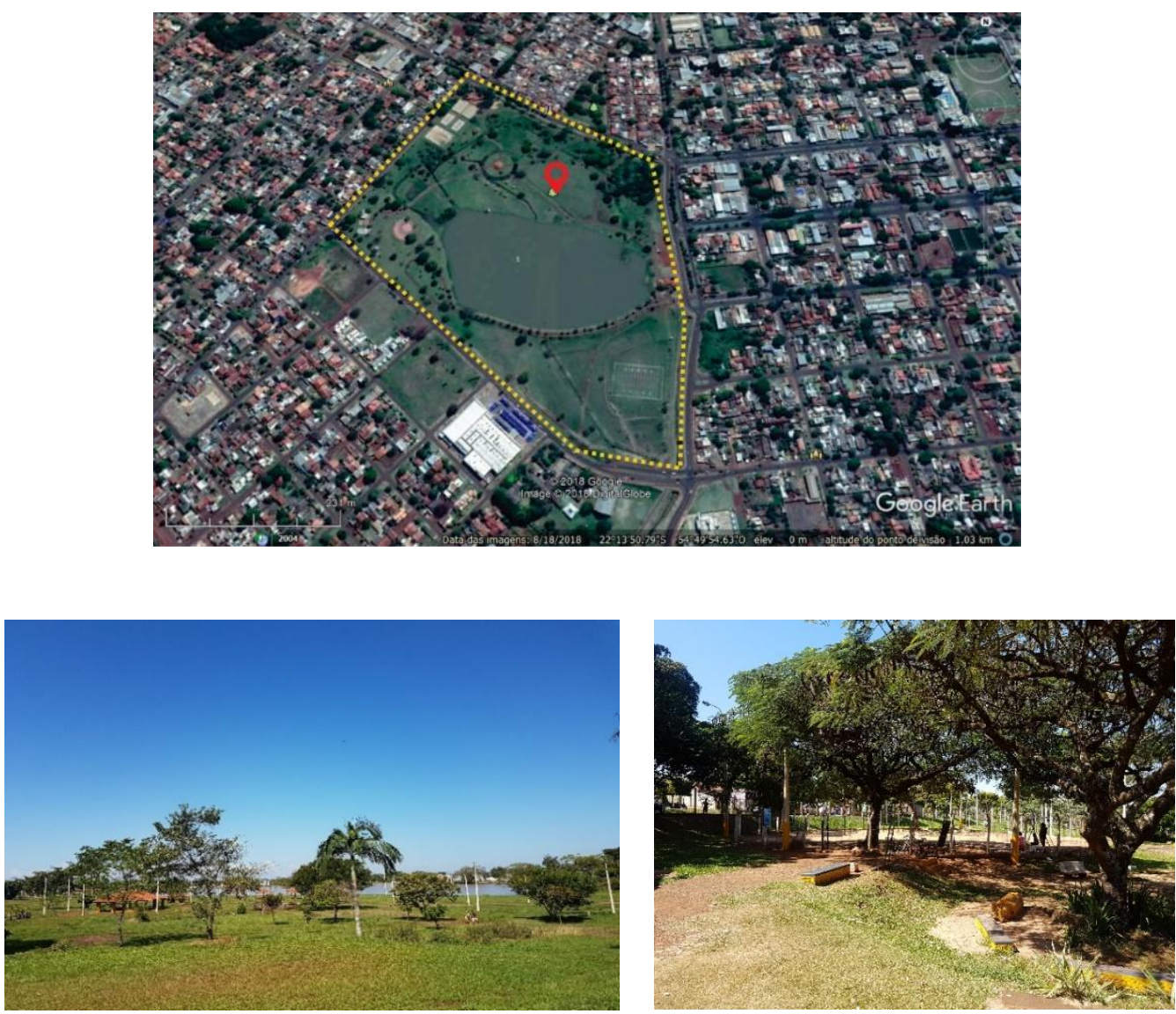

Figura 6 - Características espaciais e de estrutura física do Parque Antenor Martins. Fonte: Adaptado de Remelli, 2019. Organização: Os autores

\section{ANÁLISE DO EPISÓDIO DE INVERNO DE 2018.}

As coletas dos dados primários nos espaços livres selecionados ocorrem nos dias 18, 24, 30 de agosto e no dia 06 de setembro do ano 2018, isso nos quatro espaços selecionados. Foram aplicados nesse episódio de inverno um total de 111 questionários, abrangendo homens e mulheres, na faixa etária de 20 a 30 anos. Deste total, 63 questionários foram respondidos por mulheres, e, 48 por homens. O horário estabelecido foi das 7 horas às 17 horas, concomitante com a aplicação dos questionários foram registrados os dados de temperatura do ar, umidade do ar e velocidade do vento.

As características gerais das condições do tempo deste episódio são marcadas com temperaturas máximas que variam de $31,47^{\circ} \mathrm{C}$ até $38,26^{\circ} \mathrm{C}$, e, com mínimas de $16,80^{\circ} \mathrm{C}$ até $22,90^{\circ} \mathrm{C}$. A máxima da umidade relativa variou de $44,48 \%$ até $73,84 \%$, com mínimas de $15 \%$ a $30,96 \%$. A velocidade do vento variou de máximas de $8,40 \mathrm{~m} / \mathrm{s}$ a mínimas de $0 \mathrm{~m} / \mathrm{s}$.

No que tange a cada espaço livre analisado tem-se o seguinte quadro: 
- Praça Antônio João: foram aplicados 30 questionários do dia 18 de agosto de 2018 , seguindo a metodologia proposta. No dia a instabilidade influenciou as características do tempo de forma marcante - (Figura 7a). A maior temperatura registrada foi as $14 \mathrm{~h} 45 \mathrm{~min}$ de $32,86^{\circ} \mathrm{C}$ e a mínima no início da coleta as 7 horas com $17,15^{\circ} \mathrm{C}$. A umidade do ar teve sua máxima as $7 \mathrm{~h} 30$ min com $73,84 \%$ e a mínima as 15 horas com $23 \%$. No que se refere a velocidade do vento a máxima aferida foi de $7,60 \mathrm{~m} / \mathrm{s}$ as $8 \mathrm{~h} 15 \mathrm{~min}$ e a mínima de $0 \mathrm{~m} / \mathrm{s}$ as $11 \mathrm{~h} 30 \mathrm{~min}$ e $11 \mathrm{~h} 45 \mathrm{~min}$.

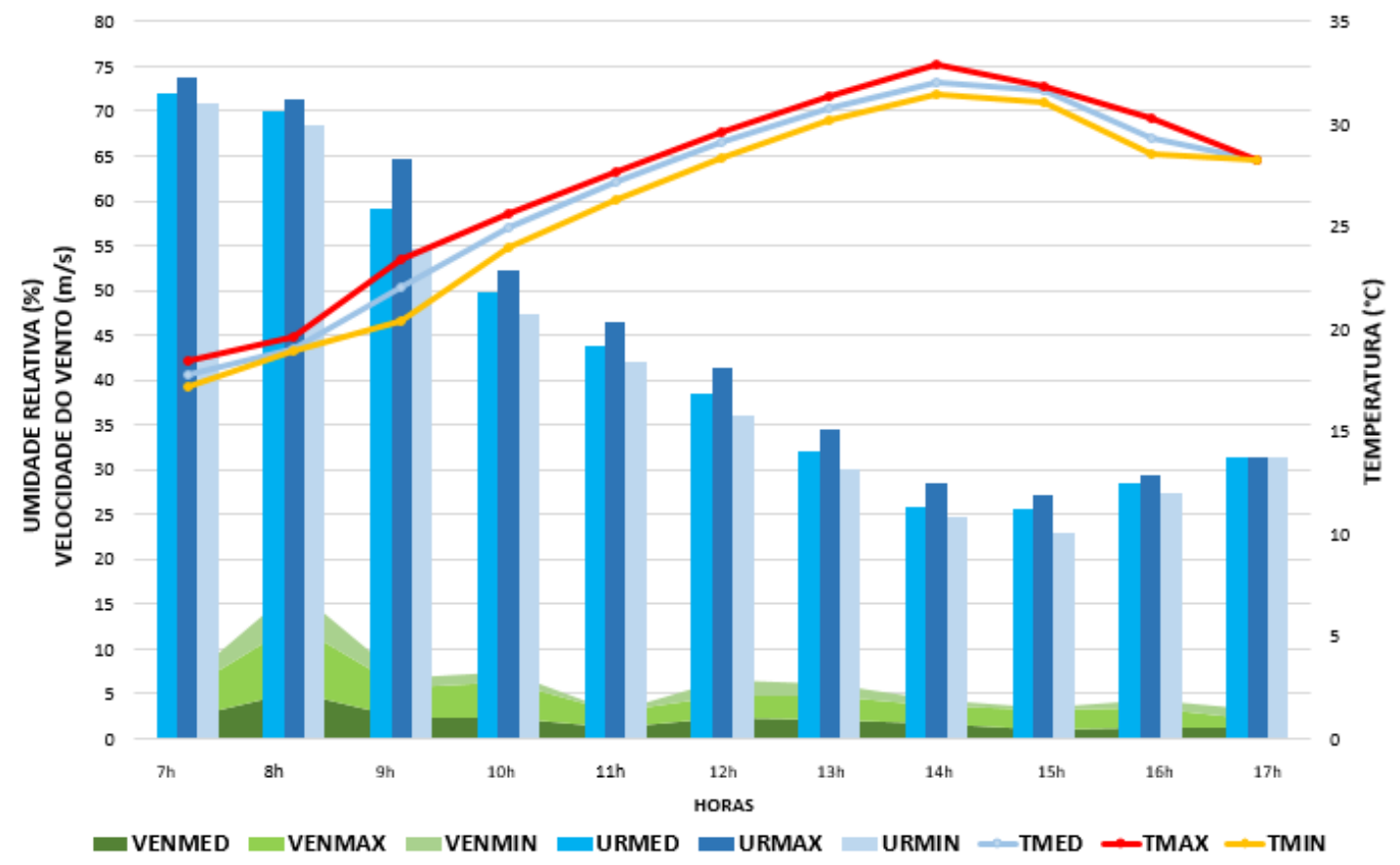

Figura 7a - Variação dos elementos do tempo - Praça Antônio João - 18/08/2018. Fonte: Adaptado de Remelli, 2019. Organização: Os autores, 2020.

O céu permaneceu sem cobertura de nuvens, devido zona de alta pressão sobre o Oceano Atlântico, adotando características subtropicais, que influência a área de estudo, cuja características proporcionam temperaturas amenas, ausência de chuva, vento brando e fresco e UR que varia de $23 \%$ a $70 \%$. É um dia típico de inverno para esta região, no qual os sistemas tropicais e polares se alteram ao longo da estação, como fica evidente perante os resultados alcançados.

Frente isso, sobre o conforto térmico ao verificar o índice de desconforto térmico (Figura 7b), o mesmo se manteve em duas classes, $80 \%$ bem-estar e $14 \%$ de parcialmente confortável, indicando que não houve mudanças significativas no tempo. O IDT faz uma aproximação maior dos resultados quando está relacionado as condições climáticas, se destacando duas classes, confortável e um pouco desconfortável, fato que não acontece ao que se refere a percepção do tempo em que são identificadas quatro classes, mas com predominância de um pouco de calor ou calor.

As respostas dos entrevistados têm pouco relação naquilo que se refere as condições climáticas do local, mais de $70 \%$ indicaram ser facilmente tolerável e 3\% que o local é dificilmente tolerável. Existe uma correlação mais direta com 
a sensação térmica, mais da metade apontou que não é necessária nenhuma mudança, situação que converge a pergunta sobre temperatura do ar, maior parte prefere que permaneça como está. Porém, o mesmo não acontece quando se refere a umidade do ar, mais da metade indica a necessidade de um ar mais úmido, e $40 \%$ de como está.

Os entrevistados indicaram que os elementos mais percebidos é a temperatura, seguido da chuva, mesmo a UR sendo um elemento importante, nesta pergunta ela é o menos percebido. Além disso, foi observado o tipo de vestimenta dos frequentadores da praça, 70\% trajavam calça e camiseta e/ou camisa (vestimenta 2) e 30\% estavam de calça e abrigo de frio (vestimenta 3 ).

Por fim, as características do local no dia não foram decisivas nas respostas, acredita-se que isto se deve os tipos de tempo predominantes, uma vez que os elementos analisados não sofreram mudanças significativas que pudessem influenciar no IDT e, portanto, na resposta.

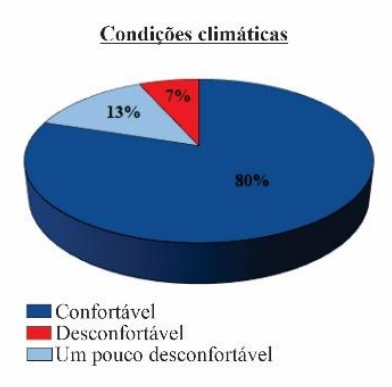

As condições climáticas do local são:

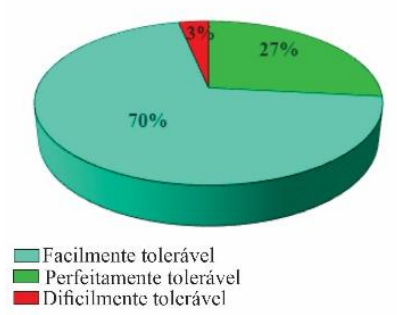

Com relação a temperatura do ar, 0 ideal seria:

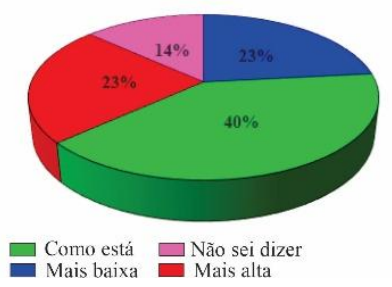

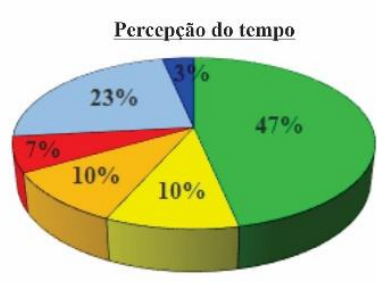

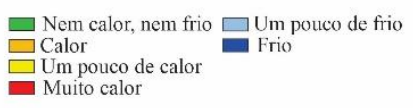

No que diz respeito a sensação térmica: o ideal é

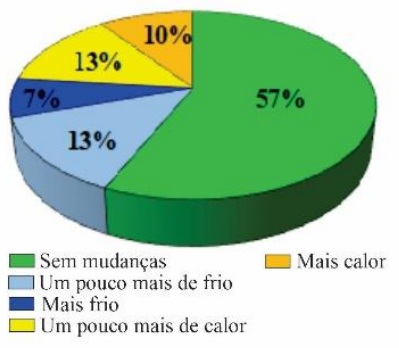

Com relação a umidade do ar, o ideal seria:

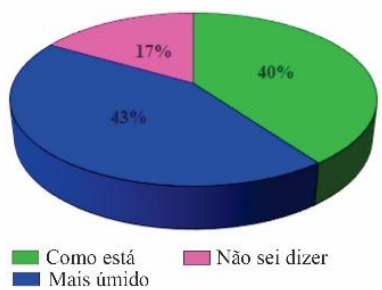

IDT - Índice de Desconforto Térmico

\begin{tabular}{|c|c|c|c|c|}
\hline \multicolumn{2}{|c|}{ Descrição } & \multicolumn{3}{|c|}{ Classes de Desconforto (ID) ${ }^{\circ} \mathrm{C}$} \\
\hline \multicolumn{2}{|c|}{ Bem Fstar (Confortaivel) } & \multicolumn{3}{|c|}{ ID $<24$} \\
\hline \multicolumn{2}{|c|}{ Parcialmente Confortável } & \multicolumn{3}{|c|}{$24<\mathrm{ID}<26$} \\
\hline \multicolumn{2}{|c|}{ Desconfortável } & \multicolumn{3}{|c|}{$26<\mathrm{ID} \geq 28$} \\
\hline \multicolumn{2}{|c|}{ Mưto Desconfortável } & \multicolumn{3}{|c|}{$\mathrm{ID} \geq 28$} \\
\hline Horário & $\begin{array}{l}\text { Hora } \\
\text { Cheia }\end{array}$ & $15^{\circ}$ & $30^{\circ}$ & $45^{\prime}$ \\
\hline $7 \mathrm{~h}$ & 16,73 & 17,25 & 17,13 & 17,81 \\
\hline $8 h$ & 18,80 & 18,20 & 18,32 & 18,68 \\
\hline 9h & 19,27 & 20,20 & 20,76 & 21,16 \\
\hline $10 \mathrm{~h}$ & 21,47 & 21,83 & 22,40 & 22,40 \\
\hline $11 \mathrm{~h}$ & 22,82 & 23,26 & 23,44 & 23,46 \\
\hline $12 \mathrm{~h}$ & 23,88 & 24,10 & 24,35 & 24,26 \\
\hline $13 \mathrm{~h}$ & 24,51 & 24,61 & 24,69 & 24,89 \\
\hline 14h & 24,80 & 24,72 & 24,64 & 25,25 \\
\hline $15 \mathrm{~h}$ & 24,52 & 24,76 & 24,43 & 24,74 \\
\hline $16 \mathrm{~h}$ & 23,96 & 23,49 & 23,26 & 23,10 \\
\hline $17 \mathrm{~h}$ & 23,07 & & & \\
\hline
\end{tabular}

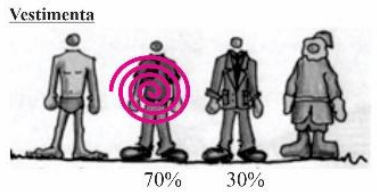

Sobre o tempo o que the chama mais atenção:

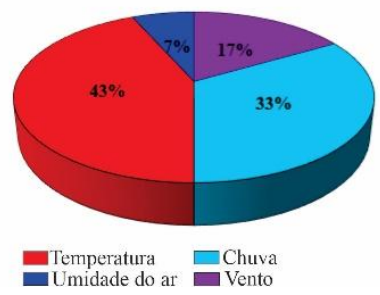

Figura 7b: Percepção do clima e conforto térmico da Praça Antônio João - 18/08/2018. Fonte: Adaptado de Remelli, 2019. Organização: Os autores

- Praça do Parque Alvorada: no dia 24 de agosto de 2018, foram aplicados 29 questionários seguindo a metodologia proposta. $O$ vento neste dia se torna um elemento importante na análise das informações coletadas, uma vez que está sempre associado a instabilidade do tempo na região, sua máxima foi registrada as $14 \mathrm{~h} 30 \mathrm{~min}$ com $8,40 \mathrm{~m} / \mathrm{s}$ e a mínima em diversos momentos do dia marcando 
$0 \mathrm{~m} / \mathrm{s}$ (Figura 8a). Diante disto é oportuno frisar que ao longo do dia em questão houve várias rajadas de ventos fortes, que está associado a mudança do tempo, o início do dia foi de céu claro e predomínio de sol pela manhã, ao meio dia a cobertura de nuvens de chuva se intensificam e na parte da tarde ocorre pancadas de chuva com granizo. A carta sinótica do dia apresenta uma frente fria entre o norte da Argentina, sul do Paraguai e o Rio Grande do Sul, associado a uma baixa pressão de $1008 \mathrm{hPa}$, sobre a região da pesquisa, que também acaba emitindo alerta de tempestade para região.

A temperatura máxima do dia foi de $34,370 \mathrm{C}$ as $13 \mathrm{~h} 45 \mathrm{~min}$ e a mínima de $21,28^{\circ} \mathrm{C}$ as 7 horas; e o maior percentual da umidade relativa do ar foi de $68,34 \%$ as $07 \mathrm{~h} 15 \mathrm{~min}$ e o menor de $30,96 \%$ as $09 \mathrm{~h} 45 \mathrm{~min}$ (Figura $8 \mathrm{a}$ ).

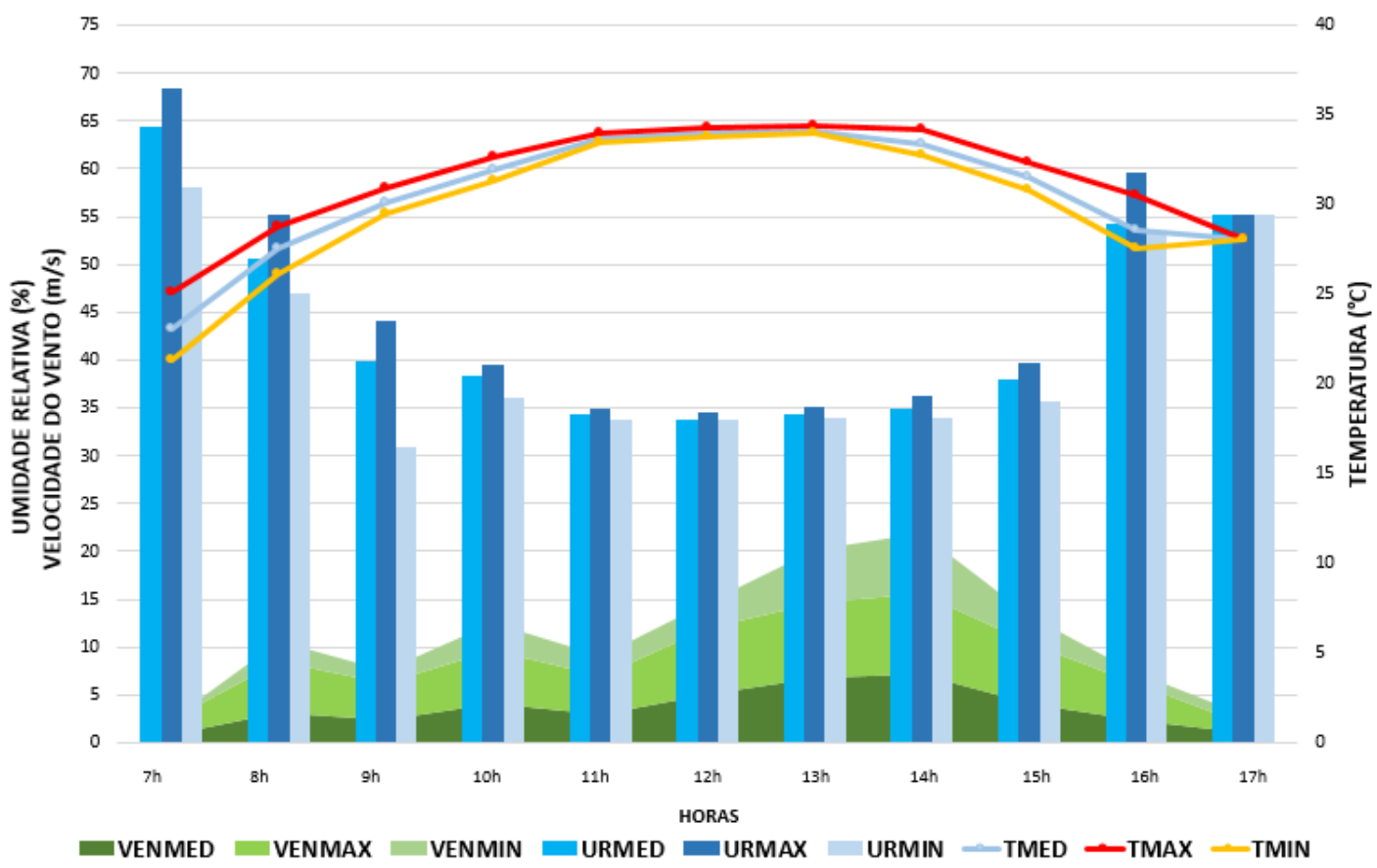

Figura 8a: Variação dos elementos do tempo - Praça do Parque Alvorada - 24/08/2018. Fonte: Adaptado de Remelli, 2019. Organização: Os autores

A partir das informações apresentadas é possível considerar que este é um dia atípico para o período de inverno, devido à instabilidade do tempo e do granizo, fato que influenciou nas condições do tempo e são refletidas no índice de desconforto térmico (Figura $8 \mathrm{~b}$ ) e naquilo que é percebido pelos frequentadores da praça.

Desta maneira, sobre a condição climática do dia, $79 \%$ se sentiam confortáveis, situação que se afasta do resultado do IDT, no entanto quando questionados sobre a percepção climática os resultados obtém maior relação com o IDT: $34 \%$ não sentem nem calor, nem frio, $31 \%$ sentem um pouco de calor, e $21 \%$ calor. Logo, sobre a sensação térmica é possível constatar cinco grupos de respostas, porém a que mais se destaca é de $62 \%$ assinalam que 0 tempo deve permanecer como está.

Sobre as condições climáticas do local, grande parte de seus frequentadores 55\%, acreditam que seja um lugar facilmente tolerável, mesmo que o mesmo não ofereça condições de permanência em situações de calor 
intenso. Naquele cenário $90 \%$ desejam que a temperatura permaneça como está, a umidade do ar $62 \%$ também desejam que não haja mudanças e $35 \%$ um ar mais úmido. O elemento apontado como o mais percebido pelos usuários é da temperatura (38\%), seguido da chuva (24\%). Além disso, foi observado o tipo de vestimenta dos frequentadores da praça, 70\% trajavam calça e camiseta e/ou camisa (vestimenta 2) e $30 \%$ estavam de calça e abrigo de frio (vestimenta 3).

A visto disto, os resultados do IDT expõem um dia de temperatura amena, com pancadas de chuva ao final da tarde, brisa fraca e umidade do ar baixa com variações de $30 \%$ à $68 \%$. Estas condições de tempo fizeram que metade do período fosse de situação desconfortável e a outra dividido em bemestar e parcialmente desconfortável.

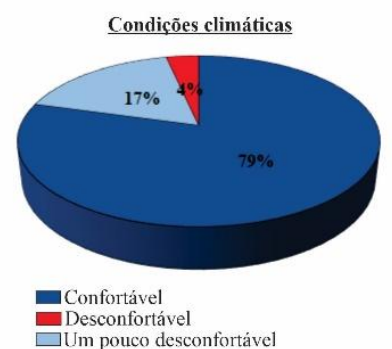

As condiçôes climáticas do local são:

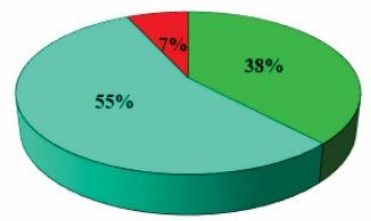

$\square$ Facilmente toleráve

Dificilmente toleráve

$\square$ Perfeitamente tolerável

Com relação a temperatura do ar, 0 ideal seria:

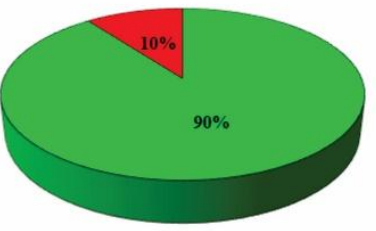

Como está

- Mais alta

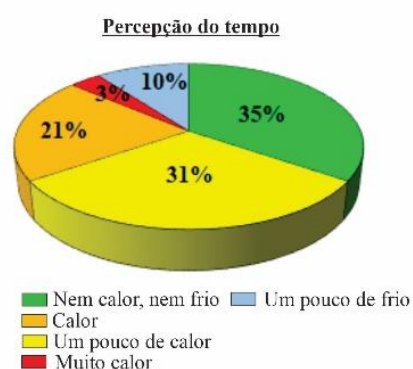

No que diz respeito a sensação térmica: o ideal é

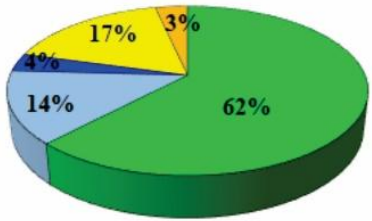

Sem mudanças $\square$ Mais calor $\square$ Um pouco mais de frio Mais frio

$\square$ Um pouco mais de calor

Com relação a umidade do ar, o ideal seria:

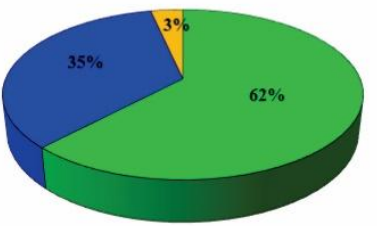

$\square$ Como está $\square$ Mais seco

\begin{tabular}{|c|c|c|c|c|}
\hline \multicolumn{5}{|c|}{ IDT - Índice de Desconforto Térmico } \\
\hline \multicolumn{2}{|c|}{ Bem Estar (Confortável) } & Classes de Desconforto $(\mathrm{ID})^{\circ} \mathrm{C}$ & \multicolumn{2}{|c|}{$\mathrm{ID}<24$} \\
\hline \multicolumn{2}{|c|}{ Parcialmente Confortável } & \multicolumn{3}{|c|}{$24<\mathrm{ID}<26$} \\
\hline \multicolumn{2}{|c|}{ Desconfortável } & \multicolumn{3}{|c|}{$26<\mathrm{ID} \geq 28$} \\
\hline \multicolumn{2}{|c|}{ Muito Desconfortável } & \multicolumn{3}{|c|}{$\mathrm{ID} \geq 28$} \\
\hline Horário & $\begin{array}{l}\text { Hora } \\
\text { Cheia }\end{array}$ & $15^{\prime}$ & $30^{\circ}$ & $45^{\circ}$ \\
\hline $7 \mathrm{~h}$ & 20,09 & 20,88 & 21,83 & 22,67 \\
\hline $8 \mathrm{~h}$ & 23,23 & 24,00 & 24,22 & 24,60 \\
\hline $9 \mathrm{~h}$ & 24,86 & 24,88 & 25,40 & 24,71 \\
\hline $10 \mathrm{~h}$ & 25,72 & 25,95 & 26,14 & 26,30 \\
\hline $11 \mathrm{~h}$ & 26,63 & 26,64 & 26,74 & 26,87 \\
\hline $12 \mathrm{~h}$ & 26,85 & 27,04 & 26,80 & 26,82 \\
\hline 13h & 26,92 & 27,00 & 26,99 & 26,51 \\
\hline $14 \mathrm{~h}$ & 27,02 & 26,44 & 26,69 & 26,39 \\
\hline 15h & 26,07 & 25,66 & 25,63 & 15,43 \\
\hline $16 \mathrm{~h}$ & 25,66 & 24,90 & 24,61 & 24,88 \\
\hline $17 \mathrm{~h}$ & 24,72 & & & \\
\hline
\end{tabular}

Vestimenta

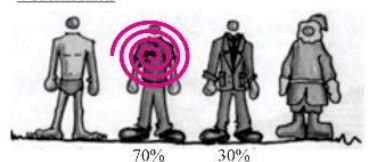

Sobre o tempo o que the chama mais atenção:

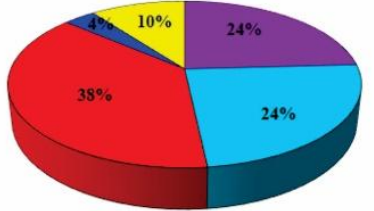

$\square$ Temperatura $\square$ Chuva $\square$ Umidade do ar Vento

Figura 8b: Percepção do clima e conforto térmico da Praça do Parque Alvorada 24/08/2018. Fonte: Adaptado de Remelli, 2019. Organização: Os autores

- Parque dos Ipês: foram aplicados 30 questionários no dia 30 de agosto de 2018 seguindo a metodologia proposta. A velocidade do vento neste dia obteve sua máxima às 13 horas com 3,20m/s e a mínima marcando $0 \mathrm{~m} / \mathrm{s}$, as 7 horas e as 15 horas; a temperatura mais elevada foi de $38,26^{\circ} \mathrm{C}$ às $13 \mathrm{~h} 30 \mathrm{~min}$ e a mínima de $22,90^{\circ} \mathrm{C}$ às 7 horas; já a umidade relativa do ar, a maior foi de $44,48 \%$ às $07 \mathrm{~h} 15 \mathrm{~min}$ e a menor de $15 \%$ às $13 \mathrm{~h} 15 \mathrm{~min}, 13 \mathrm{~h} 45 \mathrm{~min}$ e 15 horas (Figura 9a). É pertinente dizer que os valores de UR abaixo de $20 \%$ são considerados comuns para o período de inverno na região, fato este que deve ser levado em consideração principalmente naquilo que se refere ao uso da 
praça, uma vez que pode interferir na maneira como os usuários frequentam o lugar.

Neste dia o céu teve o predomínio de sol a maior parte do período, com pequenos fragmentos de nuvens cumulus. O dia foi marcado com temperaturas elevadas, umidade do ar baixa, a sensação de calor foi bem intensa, porém havia alguns momentos brisas que ajudavam a refrescar.

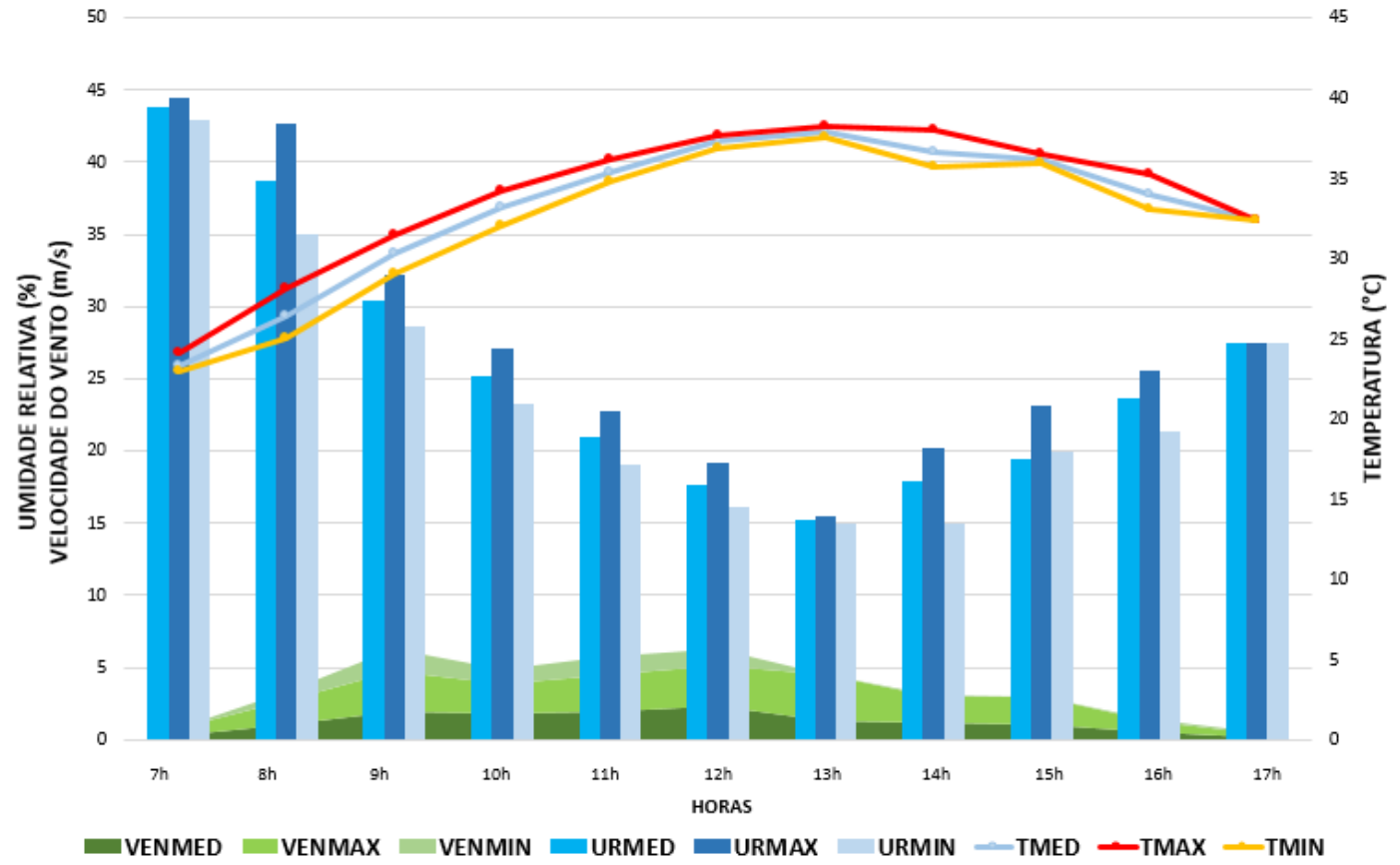

Figura 9a: Variação dos elementos do tempo - Parque dos Ipês - 30/08/2018. Fonte: Adaptado de Remelli, 2019. Organização: Os autores

Frente isso, sobre o conforto térmico (Figura 9b): sobre as condições climáticas os usuários responderam que $57 \%$ se sentem confortável, $33 \%$ um pouco desconfortável e $10 \%$ se sentia desconfortável. Ao relacionar estas informações com o resultado do IDT, é possível notar que grande parte do período foi desconfortável, situação está que válida o uso da metodologia apresentando uma correlação maior.

Quando perguntados sobre a percepção do tempo, $40 \%$ sentem calor, $30 \%$ um pouco de calor, $13 \%$ muito calor, as respostas têm maior relação com o IDT e da temperatura elevada do dia e permite correlação com as respostas sobre a sensação térmica: $43 \%$ um pouco mais de frio e $44 \%$ para sem mudanças (43\% e 44\%). Já a respeito das condições climáticas da praça, 56\% responderam ser facilmente tolerável, $38 \%$ perfeitamente tolerável e $3 \%$ respectivamente dificilmente tolerável e intolerável.

Naquilo que se refere a temperatura do ar $50 \%$ para se manter como está e $40 \%$ deseja temperatura mais baixa. Sobre a umidade do ar, $90 \%$ deseja o ar mais úmido. Mesmo que grande parte dos entrevistados desejem o ar mais úmido, os elementos indicados como mais percebidos é a temperatura e a chuva. Por último, a vestimenta 2 representou $100 \%$ daqueles que utilizaram o espaço. 
Os resultados relacionam-se e evidenciam uma correlação direta com as condições predominantes do tempo, por meio do IDT fica evidente que maior parte do dia é marcado como condição de desconforto, mesmo assim, o espaço foi muito usado e ocupado, considera-se que isso se deve ao uso de roupas apropriadas, da ausência de um tipo de tempo extremo e de características próprias do Parques dos Ipês, sua arborização.

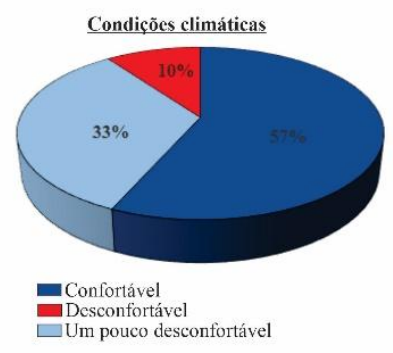

As condições climáticas do local são:

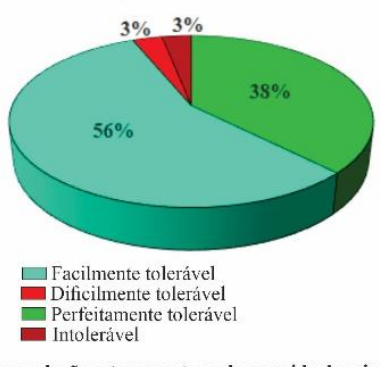

Com relação a temperatura do ar, 0 ideal seria:

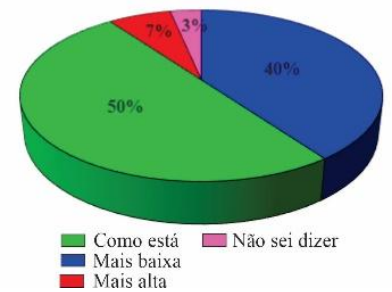

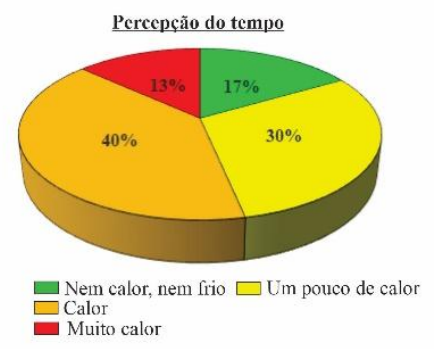

No que diz respeito a sensação térmica: 0 ideal é

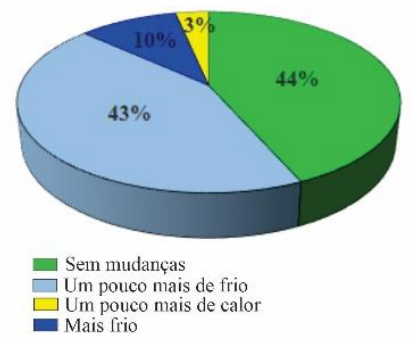

Com relação a umidade do ar, o ideal seria:

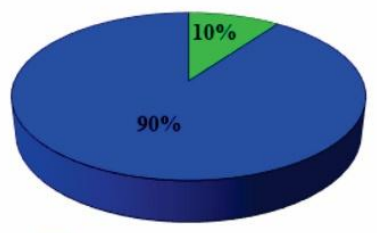

Como está

IDT - Índice de Desconforto Térmico

\begin{tabular}{|c|c|c|c|c|}
\hline \multicolumn{2}{|c|}{ Descrição } & \multicolumn{3}{|c|}{ Classes de Desconforto (ID) ${ }^{\circ} \mathrm{C}$} \\
\hline \multicolumn{2}{|c|}{ Bem Estar (Confortável) } & \multicolumn{3}{|c|}{$\mathrm{ID}<24$} \\
\hline \multicolumn{2}{|c|}{ Parcialmente Confortável } & \multicolumn{3}{|c|}{$24<\mathrm{ID}<26$} \\
\hline \multicolumn{2}{|c|}{ Desconfortável } & \multicolumn{3}{|c|}{$26<\mathrm{ID} \geq 28$} \\
\hline \multicolumn{2}{|c|}{ Muito Desconfortável } & \multicolumn{3}{|c|}{ ID $\geq 28$} \\
\hline Horário & $\begin{array}{l}\text { Hora } \\
\text { Cheia }\end{array}$ & $15^{\circ}$ & $30^{\circ}$ & $45^{\circ}$ \\
\hline $7 \mathrm{~h}$ & 20,26 & 20,27 & 20,60 & 21,08 \\
\hline $8 h$ & 21,70 & 21,59 & 22,80 & 23,27 \\
\hline $9 \mathrm{~h}$ & 23,63 & 23,98 & 24,42 & 24,83 \\
\hline $10 \mathrm{~h}$ & 25,03 & 25,36 & 25,77 & 25,86 \\
\hline $11 \mathrm{~h}$ & 26,15 & 26,26 & 26,24 & 26,52 \\
\hline $12 \mathrm{~h}$ & 26,91 & 27,02 & 27,15 & 26,89 \\
\hline 13h & 27,04 & 26,92 & 27,19 & 26,74 \\
\hline 14h & 27,04 & 26,15 & 26,48 & 26,79 \\
\hline 15h & 26,59 & 26,51 & 26,65 & 26,61 \\
\hline $16 \mathrm{~h}$ & 26,26 & 25,85 & 25,69 & 25,49 \\
\hline $17 \mathrm{~h}$ & 25,26 & & & \\
\hline
\end{tabular}

Vestimenta

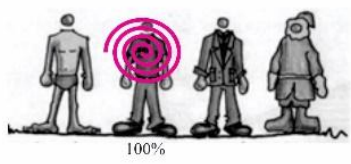

Sobre o tempo o que the chama mais atenção:

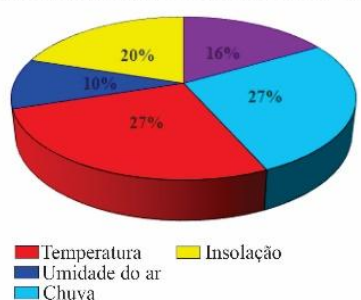

Figura 9b: Percepção do clima e conforto térmico do Parque dos Ipês 30/08/2018.Fonte: Adaptado de Remelli, 2019.Organização: Os autores

- Parque Antenor Martins: No dia 06 de setembro foram aplicados 22 questionários aos frequentadores seguindo a metodologia proposta. A temperatura mais elevada deste dia foi $31,47^{\circ} \mathrm{C}$ às $14 \mathrm{~h} 30 \mathrm{~min}$ e a mínima de $16,80^{\circ} \mathrm{C}$ às $7 \mathrm{~h} 30 \mathrm{~min}$; já a umidade relativa, a maior foi de $61,86 \%$ as $07 \mathrm{~h} 15 \mathrm{~min}$ e a mínima de $20,88 \%$ as $14 \mathrm{~h} 30 \mathrm{~min}$. Sobre a velocidade do vento, sua máxima foi as $8 \mathrm{~h} 15 \mathrm{~min}$ com $6,20 \mathrm{~m} / \mathrm{s}$ e a mínima em diversos momentos marcando 0 m/s (Figura 10a).

A carta sinótica do dia traz a informação de uma zona de alta pressão pós-frontal com atuação no Uruguai e o Sudeste do Brasil, fato que pode explicar a ausência de nuvens neste dia, sendo um dia de elevada temperatura do ar e baixa umidade do ar, sem a ocorrência de chuva e céu claro e predomínio de sol. 


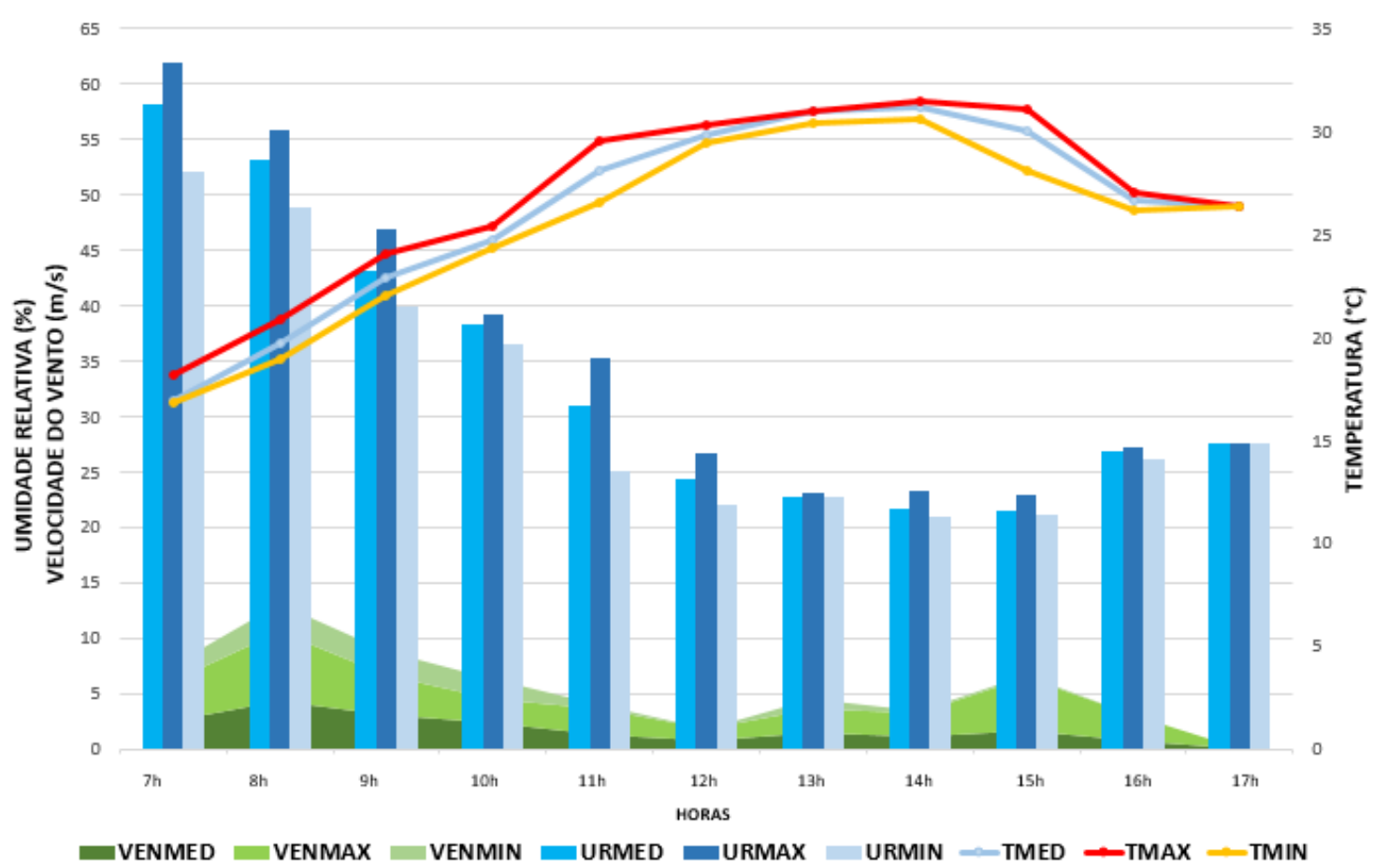

Figura 10a: Variação dos elementos do tempo - Parque Antenor Martins - 06/09/2018. Fonte: Adaptado de Remelli, 2019. Organização: Os autores

Quando analisadas as informações sobre conforto térmico (Figura 10b), mais especificadamente sobre as condições climáticas, $72 \%$ se sentiam confortável e $14 \%$ um pouco desconfortável, situação está que se relaciona com o IDT, já que grande parte do período foi classificada como confortável. O mesmo não se verifica quando indagados sobre a percepção, que apresenta a predominância de nem calor e nem frio (59\%).

No que diz respeito a sensação térmica, 64\% apontou que não era necessária nenhuma mudança. Já sobre as condições climáticas do parque $91 \%$ indicou ser facilmente tolerável e $9 \%$ perfeitamente tolerável. Sobre a temperatura do ar $77 \%$ deseja que não haja mudanças e $14 \%$ prefere que esteja mais alta, já sobre a UR mais da metade deseja um ar mais úmido. Mesmo se desejando o ar mais úmido, este elemento é o último a ser destacado pelos entrevistados, a temperatura e a insolação são apontadas como elemento mais percebido, $32 \%$ ambos.

Por último, no que se refere ao tipo de vestimenta dos usuários $90,90 \%$ deles usavam a vestimenta 2 , e 9,1\% com vestimentas 3 .

Em síntese, os resultados não interferiram diretamente no IDT apresentado, uma vez que indicam características típicas do inverno desta região, uma estação seca, com alternância de tipos de tempo que favorecem temperaturas variadas que podem ficar acima de $20^{\circ} \mathrm{C}$ em alguns dias e outros abaixo de $10^{\circ} \mathrm{C}$. 


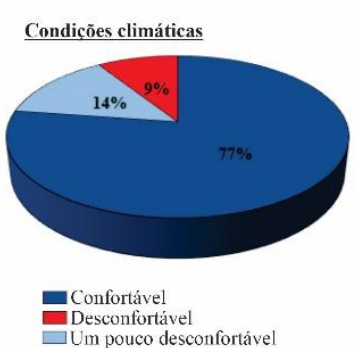

As condiçôes climáticas do local são:

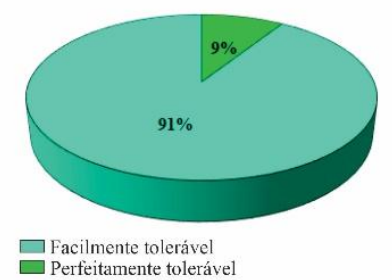

Com relação a temperatura do ar, o ideal seria:

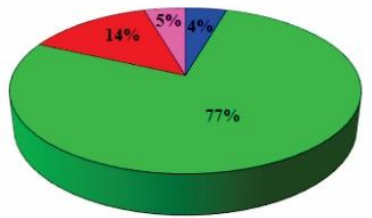

Como está $\square$ Não sei dizer Mais baixa

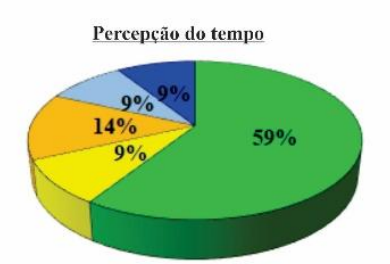

$\square$ Nem calor, nem frio $\square$ Um pouco de frio $\square$ Calor

No que diz respeito a sensação térmica: o ideal é

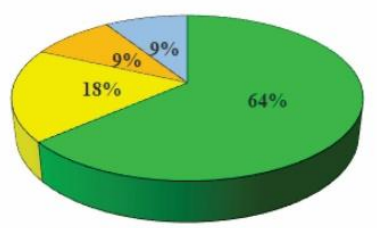

Sem mudanças

Uim pouco mais de frio

Um pouco mais de calor

$\square$ Mais calor

Com relação a umidade do ar, o ideal seria:

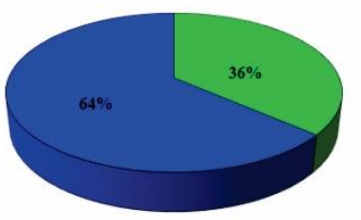

Como está
IDT - Índice de Desconforto Térmico

\begin{tabular}{|c|c|c|c|c|}
\hline \multicolumn{2}{|c|}{ Descrição } & \multicolumn{3}{|c|}{ Classes de Desconforto (ID) ${ }^{\circ} \mathrm{C}$} \\
\hline \multicolumn{2}{|c|}{ Bem Estar (Confortável) } & \multicolumn{3}{|c|}{$\mathrm{ID}<24$} \\
\hline \multicolumn{2}{|c|}{ Parcialmente Confortável } & \multicolumn{3}{|c|}{$24<\mathrm{ID}<26$} \\
\hline \multicolumn{2}{|c|}{ Desconfortável } & \multicolumn{3}{|c|}{$26<11) \geq 28$} \\
\hline \multicolumn{2}{|c|}{ Mưto Desconfortável } & \multicolumn{3}{|c|}{$\mathrm{ID}>28$} \\
\hline Horário & $\begin{array}{l}\text { Hora } \\
\text { Cheia }\end{array}$ & 15 & $30^{\circ}$ & $45^{\circ}$ \\
\hline $7 \mathrm{~h}$ & 15,85 & 15,87 & 16,31 & 17,30 \\
\hline $8 \mathrm{~h}$ & 17,90 & 18,09 & 18,46 & 19,10 \\
\hline 9h & 19,84 & 19,95 & 20,44 & 20,90 \\
\hline $10 \mathrm{~h}$ & 21,12 & 20,99 & 21,37 & 21,37 \\
\hline $11 \mathrm{~h}$ & 21,61 & 22,28 & 22,94 & 23,34 \\
\hline $12 \mathrm{~h}$ & 23,55 & 23,24 & 23,47 & 23,61 \\
\hline 13h & 23,61 & 24,24 & 24,18 & 23,97 \\
\hline $14 \mathrm{~h}$ & 23,84 & 24,06 & 24,03 & 24,03 \\
\hline $15 \mathrm{~h}$ & 23,95 & 23,76 & 23,23 & 22,36 \\
\hline $16 \mathrm{~h}$ & 22,01 & 21,59 & 21,51 & 23,69 \\
\hline $17 \mathrm{~h}$ & 26,66 & & & \\
\hline
\end{tabular}

Vestimenta

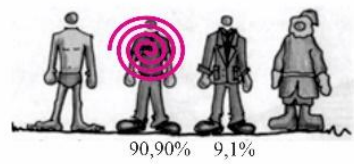

Sobre o tempo o que the chama mais atencão:

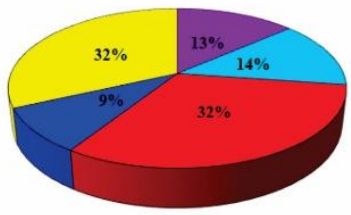

- Temperatura $\square$ Insolação $\square$ Chuva

Figura 10b: Percepção do clima e conforto térmico da Parque Antenor Martins 06/09/2018. Fonte: Adaptado de Remelli, 2019. Organização: Os autores

\section{CONCLUSÕES}

A partir da década de 1970 observou-se o crescimento e o surgimento de cidades na região Centro-Oeste brasileira, isso derivado do avanço do agronegócio voltado ao plantio de commodities e de políticas públicas com objetivos de diminuir o déficit habitacional do país. É nesse cenário que se observa o crescimento das cidades continentais como Dourados, que enquadrase nesse perfil. Os estudos de clima urbano assim têm ganhado importância onde observa-se alterações dos padrões climáticos na escala local e no urbano dessa cidade, isso em função do modelo de crescimento implementado que atrela especulação imobiliária versus renda da terra.

A pesquisa permitiu concluir a relação dos moradores de Dourados com seus espaços livres, tendo o conforto térmico e percepção do calor como temas centrais. A metodologia escolhida, as referências teóricas e as técnicas para coleta de dados se demonstraram eficientes. A escolha, os parâmetros de temperatura, umidade relativa, correlacionados com a circulação atmosférica regional e a aplicação de questionários permitiu qualificar e quantificar a percepção do calor, definir as faixas de (des)conforto térmico com clareza. Observa-se que a construção metodológica é passível de ser replicada em outros estudos com os mesmos objetivos, o que permite um avanço nas pesquisas que envolvem o estudo do clima urbano no Brasil. 
Mediante os questionários aplicados é possível afirmar que este espaço livre é usado mais intensivamente quando se tem atividades que sejam destinadas para a comunidade, caso contrário, é ocupado de forma efêmera, por aqueles que esperam o ônibus, a hora para trabalhar, o descanso do almoço, a ida na igreja, conversar com os amigos e para a paquera. Os espaços públicos se tornam assim algo de passagem para pessoas.

No que diz respeito a frequência as condições do tempo demonstraramse um elemento importante, a maioria dos usuários usam o espaço uma vez na semana, não o usando em dias de chuva com temperaturas elevadas. Para que o visitem é necessário que esteja um dia com tempo estável e agradável, sem chuva e com a temperatura amena. De maneira geral é possível avaliar que no início da manhã o tempo se apresentava mais agradável, com temperaturas amenas que variaram de $16,80^{\circ} \mathrm{C}$ a $22,90^{\circ} \mathrm{C}$.

Em dias específicos, como no dia 06 de setembro, marcado por temperaturas baixas de $16,80^{\circ} \mathrm{C}$, o vento tornou o tempo desagradável, causando desconforto para aqueles que estiveram presente no espaço livre analisado. O mesmo ocorreu quando a temperatura atingiu seu máximo $38,26^{\circ} \mathrm{C}$, dia 30 de agosto. Nesse dia observou-se a importância de se proteger nas sombras das árvores e dos prédios, somado a outros cuidados como hidratação e proteção solar devido ao (des)conforto causado pelo trinômio padrão construtivo dos locais, condições do tempo e ausência de elementos que pudessem amenizar o desconforto término.

Em um momento que se observa o aumento de episódios de ondas de calor torna-se essencial compreender o clima urbano das cidades brasileiras. Desse modo, espera-se que o estudo colabore com pesquisas de clima urbano em cidades continentais, essencialmente aquelas que apresentam característica de altas temperaturas, as que tem seus climas regulados, influenciados, por características continentais. Para mais, coopere em preposições de orientação para gestão e uso de espaços livres em cidades, no qual as características climáticas sejam elementos importantes nas definições das políticas públicas que viabilizam o crescimento urbano.

\section{AGRADECIMENTOS}

A CAPES pelo financiamento do projeto na forma de bolsa de estudos, condição essencial para execução e término da pesquisa e capacitação profissional.

\section{REFERÊNCIAS}

ANDRADE, C. S.P. de. A Climatologia da Cidade de Teresina-PI: as variantes topoclimáticas dos espaços livres. Tese. Recife, 2009.

COUTINHO, M. D. L.; SANTOS, T. S. DOS; GOMES, A. C. DOS S.; SILVA, A. R.; COSTA, M. DA S.; MORAIS, M. D. C. DE. O Microclima E O (Des)Conforto Térmico Em Ambientes Abertos $\mathrm{Na}$ Cidade De Natal. Hygeia - Revista Brasileira de Geografia Médica e da Saúde. V. 10, n. 19, p. 65 - 73, 17 dez. 2014.

DUMAZEDIER, J. Lazer e cultura popular. São Paulo: Perspectiva, 1973. 
FANTE, Karime Pechutti; DUBREUIL, Vincent e SANT'ANNA NETO, João Lima. Avaliação comparativa entre metodologias de identificação de situações de conforto térmico humano aplicado ao contexto tropical, Presidente Prudente/Brasil. Revista Brasileira de Climatologia. Ano 13, Vol. 21, Jul/Dez de 2017.

FIETZ. C.R.; FISCH, G.F. O clima da Região de Dourados, MS - Embrapa (MS), Documentos 92 - 20 Edição, abril de 2008.

FIETZ. C.R; FISCH, G.F; CAMUNELLO. E; FLUMIGNAN. D.L. O clima da Região de Dourados, MS - Empraba (MS), Documentos 138 - 30 Edição, versão atualizada, novembro de 2017.

GOBO, J. P. de A. Bioclimatologia Subtropical E Modelização Do Conforto Humano: da escala local à regional. Tese (Doutorado) - Faculdade de Filosofia, Letras e Ciências Humanas, Universidade de São Paulo. São Paulo - SP, 2017.

GOMES, S. de T. Clima Urbano de Dourados (MS): uma análise a partir do processo de urbanização. 2012. Dissertação (Mestrado em Geografia). Universidade Federal da Grande Dourados, Dourados/MS.

INSTITUTO BRASILEIRO DE GEOGRAFIA E ESTATÍSTICA (IBGE). Censo Brasileiro de 2010. Rio de Janeiro: IBGE, 2012. INSTITUTO BRASILEIRO DE GEOGRAFIA E ESTATÍSTICA (IBGE).

LIMA, V; AMORIN, M. C. de C. T. A Importância das Áreas Verdes para a Qualidade Ambiental das Cidades. Revista Formação, no13, p. 139 - 165, 2006.

LOPES, L. C. S.; JARDIM, C. H. Variações de temperatura e umidade do ar em área urbana e rural durante o seguimento temporal de inverno de $2011 \mathrm{em}$ Contagem e Betim (MG). Acta Geográfica. v. 1, p. 205-2221, 2012.

LOMBARDO, M. A. Ilha de Calor das Metrópoles: o exemplo de São Paulo. Editora Hucitec, São Paulo, 1985.

RAMPAZZO, C. R; SANT'ANNA NETTO, J. L. Clima e Qualidade Ambiental Urbana em Alfredo Marcondes/SP: análise em episódio de inverno. REVISTA GEONORTE, Edição Especial 2, V.2, N.5, p. 194- 206, 2012.

OKE, T. R. Boundary Layer Climates. London: Methuem\& Ltd. A. Halsted Press Book, John Wiley \& Sons, New York, 1978, p. 372.

REMELLI, A. G. A Percepção do Clima e os Usos dos Espaços Livres na Cidade de Dourados-MS/Brasil. Dissertação (Mestrado). Universidade Federal da Grande Dourados. Dourados, 2019.

REMELLI, A. G.; SILVA, C. A. Critérios para escolha de espaços livres visando estudos de clima urbano e a percepção do clima e tipos de tempo. In: XIII Simpósio Brasileiro de Climatologia Geográfica. 2018, Juiz de Fora. XIII Simpósio Brasileiro de Climatologia Geográfica: A Climatologia Geográfica Brasileira: o ensino, os métodos, as técnicas e os desafios para o século XXI. Anais eletrônicos. Juiz de Fora (MG): ABClima/UFJF, 2018. p. 330-340.

Disponível

em: www.abclima.ggf.br/sbcg2018/site/anais/arquivos/323/d40ad28b80089048d014 906db7287352.pdf. Acesso em 14 Fev. 2019. 
SANTOS, M. A natureza do espaço: técnica e tempo, razão e emoção. São Paulo. Hucitec. 1999.

SANTOS, J. S., SILVA, V. P. R, SILVA, E.R., ARAUJO, L.E.; COSTA, A. D. Campo térmico urbano e a sua relação com o uso e cobertura do solo em cidade tropical. Revista Brasileira de Geografia Física, Recife-PE, v. 5, n. 3, p. 540557, 2012.

SANTOS, V. A. dos. Sistema Clima Urbano e Ritmo Climático de Dourados (MS): os subsistemas físico-químico e termodinâmico. Qualificação da Tese, Universidade Federal da Grande Dourados. Dourados -MS, 2018.

SARTORI, M. da G. B. Clima e Percepção Geográfica: fundamentos teóricos à percepção climática e á bioclimatologia humana. Gráfica Editora Pallotti. Santa Maria, 2014.

SILVA, J. F. da. FERREIRA, H. dos S. SANTOS, Marcelo Olímpio dos. Considerações Sobre os Estudos em Clima Urbano. Revista GEAMA, Recife, v.1, n.2, mês - setembro, 2015.

SCHNEIDER, H; SILVA, C. A. da. Revista Eletrônica da Associação dos Geógrafos Brasileiros - Seção Três Lagoas/MS - no 16 - Ano 9, novembro, 2012.

THOM, E.C. The Discomfort Index. Weatherwise, Boston, 12(1), p. 57-60, 1959.

TROPPMAIR, H; GALINA, M. H. Território \& Cidadania. Ano III, Número 2, julho - dezembro de 2003.

VIANA, S. S. M. Conforto térmico nas Escolas Estaduais de Presidente Prudente/SP. Tese (Doutorado). Universidade Estadual Paulista " Júlio de Mesquita Filho". Presidente Prudente, 2012.

ZAVATTINI. J. A. As chuvas e as massas de ar no estado de Mato Grosso do Sul: estudo geográfico com vista à regionalização climática. São Paulo. Editora UNESP; São Paulo: Cultura Acadêmica, 2009. p. 212 